\title{
A DIRETIVA (UE) 2015/2302 DO PARLAMENTO EUROPEU E DO CONSELHO NA INTEGRAÇÃO EM REDE DA UNIÃO EUROPEIA NO SETOR DO TURISMO.
}

\author{
VIRGÍLIO MACHADO ${ }^{1}$ \\ Professor Adjunto da Escola Superior de Gestão da Escola Superior de Gestão, \\ Hotelaria e Turismo da Universidade do Algarve (PORTUGAL) \\ JOÃO ALMEIDA VIDAL ${ }^{2}$ \\ Professor Auxiliar Convidado da Faculdade de Economia da Universidade do \\ Algarve (PORTUGAL) \\ AFONSO PEDRO RIBEIRO CAFÉ ${ }^{3}$ \\ Assistente Convidado da Faculdade de Economia da Universidade do Algarve, \\ (PORTUGAL)
}

\begin{abstract}
É objeto da presente investigação questionar e responder se a Diretiva 2015/2302, do Parlamento Europeu e do Conselho, de 25 de Novembro de 2015, sobre viagens organizadas e serviços de viagens conexos, constitui um elemento constituinte na integração jurídicoeconómica em rede da União Europeia. Tal desafio, não só reforça a dogmática da doutrina sobre Direito Comunitário do Turismo, mas essencialmente constitui uma abordagem ao diagnóstico de ferramentas, técnicas e instrumentos para o estudo da regulação do turismo como elemento constituinte de uma organização em rede dos Estados Membros da União Europeia, visão que tem sido pouco abordada, tanto na literatura científica, como nas próprias políticas e estratégias daquela organização em geral.
\end{abstract}

As principais alterações introduzidas pela Diretiva passaram pela adaptação do regime aos meios eletrónicos de comercialização de produtos e serviços turísticos, com novas tipologias de atores no mercado e novos processos de contratação e vinculação, alargando-o a outras realidades até aqui carentes de regulação e desprotegidas na protecção dos direitos do consumidor, ora designado viajante.

Propomo-nos proceder à análise crítica do diploma no que toca ao nível de harmonização que o legislador impôs na transposição, a fim de aferir se tal limitação à liberdade dos vários ordenamentos jurídicos nacionais tem, como consequência, vantagens para a organização em rede do mercado turístico e seus intervenientes, bem como à nova

\footnotetext{
${ }^{1}$ vrmachado@ualg.pt

2 jvidal@ualg.pt

3 apcafe@ualg.pt
} 
regulamentação relativa aos sujeitos e processos contratuais na relação jurídica de viagem organizada e de serviço de viagem conexo. Propomo-nos ainda aferir até que ponto, e com que eficácia, se o novo diploma legal logrou cumprir objetivos de protecção do consumidor, ora designado viajante, se antes procurou padronizar as condições contratuais de funcionamento da oferta turistica.

Palavras- chave: turismo, viagem organizada, serviço de viagem conexo, pacote dinâmico, direito do turismo, rede, padronização, integração, informação, organização, operador.

\section{INTRODUÇÃO. O PROBLEMA DA INVESTIGAÇÃO}

O turismo é entendido por vasta literatura científica e técnica como uma forma de organização híbrida de colaboração, interdependência, resultando do cruzamento de outras formas de organização entre mercado e empresa ${ }^{4}$, próprias de uma sociedade em rede ${ }^{5}$ ampliada pelas possibilidades abertas pelas novas tecnologias de informação e comunicação.

O regime jurídico das viagens organizadas na União Europeia tem sido regulado pela Diretiva 90/314/CE, a qual estabeleceu as regras básicas que disciplinariam uma uniformização das normas relativas às viagens organizadas, férias organizadas e circuitos organizados, com vista a, segundo o preambulo do diploma, fazer cessar as diferentes práticas existentes nos Estados-Membros, as quais, criavam "obstáculos à livre prestação de serviços no que respeita às viagens organizadas e distorções de concorrência entre os operadores estabelecidos nos diferentes Estados-membros“.

Tal diretiva estabeleceu os limites mínimos impostos às legislações dos Estadosmembros e a sua transposição pela generalidade dos ordenamentos jurídicos estabeleceu, pela primeira vez, um standard mínimo de proteção aplicável às viagens organizadas no espaço europeu.

Desde a aprovação da Diretiva em 1990 todo o mundo se alterou e, com ele, também o turismo.

O turismo é hoje uma atividade com um enorme carácter concorrencial. O mercado turístico é caracterizado por permitir a existência de agentes de grande dimensão em concorrência direta com pequenas e médias empresas ${ }^{6}$. As empresas turísticas são, no entanto, fortemente interdependentes entre si, oferecendo, por um lado, serviços que se complementam e que agrupados constituem uma viagem turística, e por outro lado, composto de empresas concorrentes no mesmo mercado ${ }^{7}$, o que potencia a aptidão destas empresas para uma

\footnotetext{
${ }^{4}$ Vid. por todos, Costa, Towards the improvement of the efficiency and effectiveness of tourism planning and development at the regional level: planning, organizations and networks, Guildford, Surrey University, 1996.

${ }^{5}$ Castells, M. ,The Rise of the Network Society, Blackwell Publishers Inc., Cambridge, Massachusetts, 1996.

${ }^{6}$ O que caracteriza o mercado turístico entre o oligopólio e a concorrência monopolística, Vid. MAK J., Tourism and Economy, Understanding the Economy of Tourism, University of Harvard Press, 2004.

${ }^{7}$ Vid. BULL, A., Industrial Economics and Pricing Issues Within Tourism Enterprises and Markets, Dwyer L e Forsyth P (Eds.), International Handbook of the Economics of Tourism, Northampton, Edward Elgar Publishing, 2006.
} 
organização em rede, marcada simultaneamente, por características de autonomia e interdependência ${ }^{8}$.

Como em muitas outras atividades económicas, no turismo a revolução tecnológica alterou por completo os modelos de negócio. Esta enorme transformação permitiu a criação de novas empresas e inovadores modelos de negócios que, com grande sucesso, alteraram o panorama da atividade e dos atores no mercado turístico ${ }^{9}$.

O regime aprovado pela Diretiva de 1990 tornou-se desajustado às necessidades de regulação da viagem turística, não prevendo, nomeadamente, os casos em que esta era comercializada por meios eletrónicos, inexistentes aquando da aprovação do diploma.

Na medida em que o Direito tem necessidade de acompanhar a evolução do contexto social e económico, estabelecendo regras, por forma a assegurar a certeza e segurança necessária ao desenvolvimento das atividades sociais e económicas a União Europeia deve fazer evoluir as regras de troca para reduzir a complexidade dos mecanismos de negociação e contratualização entre os agentes económicos e sociais, articulando-os e padronizando-os com os objetivos comunitários.

A Diretiva UE 2015/2302, de 25 de Novembro de 2015, veio regular o regime das viagens organizadas e serviços de viagem conexos, enunciando como principais preocupações a adaptação do regime da viagem organizada à evolução tecnológica verificada no mundo e, consequentemente, também no mercado turístico, oferecendo maiores garantias de uma maior proteção ao consumidor ${ }^{10}$.

O legislador pretende estabelecer uma regulação pormenorizada do regime da viagem organizada que é considerado como uma parte significativa do mercado das viagens, representando o turismo, também, um papel importante na economia da União (Considerandos 1 e 2, respectivamente).

Veremos como o conceito de viagem organizada abrangendo realidades que se encontravam excluídas da Diretiva 90/314/CE, bem como a enunciação de uma série de direitos do viajante e obrigações das entidades organizadoras ou facilitadoras da oferta de serviços turísticos, os denominados “operadores" no âmbito da relação contratual, nomeadamente, através do estabelecimento de obrigatoriedade de detalhadas informações prévias à celebração do contrato, as quais se transformam em cláusulas contratuais e vinculativas, à necessária proteção perante insolvência ${ }^{11} \mathrm{e}$ as fichas informativas normalizadas constantes do Anexo à Diretiva (Anexos I e II) vão, de facto, impulsionar uma nova estruturação comunitária abrangente e integrada do mercado das viagens e turismo, retirando aos Estados Membros substancial autonomia regulatória para o efeito.

\footnotetext{
${ }^{8}$ ALLEE,V.«The value Evolution: Adressing Larger Implications of an Intellectual Capital and Intangible Perspective», Journal of Intellectual Capital, vol. 1, $\mathrm{n}^{\circ}$ 1,2000

9 BATUECAS, A e APARÍCIO J, La contratación online de servicios turísticos, Nuevas fórmulas de comercialização on line de servicios turísticos: subsunción en los tipos legales y distribución de responsabilidad, PANIZA A. (Eds.), Editorial Comares, Granada, 2013, p. 49; JAMAL, T., Robinson M., The SAGE Handbook of Tourist Studies, SAGE Publications, London, 2009, Pag. 5 e BUHALIS, D., LAW R., Progress in information technology and tourism management: 20 years on and 10 years after the Internet-The state of eTourism research, Tourism Management, Volume 29, issue 4, Elsevier, Pag. 609.

${ }^{10}$ Que agora se denomina, no âmbito deste diploma, “viajante”, conforme trataremos infra.

${ }^{11}$ Esta aplicável também aos casos de comercialização de serviços conexos, através do artigo 19. ${ }^{\circ}$ da Diretiva.
} 
Assim, responder-se-á ao problema de investigação colocado, i.e. se a Diretiva 2015/2302, do Parlamento Europeu e do Conselho, de 25 de Novembro de 2015, sobre viagens organizadas e serviços de viagens conexos, constitui um elemento federador na oferta e venda de viagens e serviços turísticos, permitindo, num sector importante da economia da União, uma integração jurídico- económica em rede no território dos Estados Membros que a compõem. Este estudo será feito a partir da análise jurídica de algumas das mais relevantes alterações trazidas pela nova Diretiva, a saber, conceito de viagem organizada, nível de harmonização, sujeitos contratuais e responsabilidade dos diversos intervenientes.

\section{METODOLOGIA}

Assume-se neste artigo que os assuntos são tratados a partir da Teoria e Política do Direito, dos Sistemas de Turismo, procurando-se a deteção de índices, pelo Direito, de constrangimentos, faculdades, vantagens que manifestam adjudicações vinculativas de poder $^{12}$ nas relações entre União Europeia e Estados- Membros, por um lado, e, por outro, entre os ofertantes/ facilitadores de viagens e serviços turísticos e os consumidores.

Procurar-se-á saber como observar, descrever e explicar instrumentos, ferramentas e técnicas jurídicas que permitam a consolidação de uma organização na oferta e venda de serviços e viagens turísticas em rede no espaço da União Europeia e que consolidam uma visão, uma evolução para um mercado integrado de viagens e turismo no território dos Estados Membros que a compõem.

A perspetiva sistemática, com a procura de uma ordem ou sentido à investigação pelo enunciado de questões fundamentais da investigação ${ }^{13}$ (quem, o quê, como) e teleológica ${ }^{14}$ (hierarquização de interesses ou fins subjacentes à norma) darão uma perspetiva coerente de análise e interpretação ao problema de investigação colocado.

Por outro lado, esta pesquisa sistemática e dedutiva é complementada com uma outra aplicada a um estudo de caso: a Diretiva das viagens organizadas e serviços de viagens conexos. Questiona-se se o estudo de caso tem possibilidade de produzir alguma generalização ou teoria causal dotada de alguma veracidade. Defende-se, na senda de Bartolini, ${ }^{15}$ que tal estudo tem valor quando toma em consideração uma grande quantidade de propriedades susceptíveis de esclarecer, em termos descritivos e de argumentação factual, a complexidade do problema de investigação.

Este regime, estudado pelo seu carácter abrangente (viagens organizadas que agregam conjuntos de serviços turísticos e intermediação e facilitação destes na venda), inserido num conjunto de 28 Estados que constituem o território da União Europeia, constitui um exemplo relevante de padronização duradoura de obrigações e deveres contratuais de organizações turisticas perante centenas de milhões de consumidores e que exprimem deveres de interesse económico geral e de ordem pública.

\footnotetext{
${ }^{12}$ Vid. Pires, F.L. Introdução à Ciência Política, Porto, Universidade Católica Portuguesa,1998.

${ }^{13}$ Vid. Ferris, T. Ciência e Liberdade- Democracia, razão e leis da natureza. Lisboa, Gradiva, 2013.

${ }^{14}$ Vid. Pereira, A.M. Introdução ao Direito e às Obrigações, 4 a edição, Coimbra, Almedina, 2015.

15 Vid. Bartolini, S. “Metodologia de la investigación política” en e. a. G.Pasquino, Ed. Manual de Ciência Política, Madrid, Alianza Universidad, 1994.
} 
Como se verá e concluirá, afinal, esta dinâmica insere-se, na acepção de Assens ${ }^{16}$, no valor que a informação representa na economia do conhecimento e em rede, muito relevantes para a atividade empresarial em turismo, viagens turisticas e serviços turísticos.

Assim, a metodologia utilizada observará índices de manifestação vinculativa, integradora e padronizadora de poder, pelo Direito, com recurso a análises de interpretação sistémica (quem, o quê e como) e teleológica (hierarquização de interesses) de um regime jurídico considerado exemplar e relevante para o problema de investigação colocado.

\section{O NÍVEL DE HARMONIZAÇÃO}

Uma primeira análise sistémica (o quem na relação entre União Europeia/ Estados Membros) incide sobre o nível de harmonização exigido pelo legislador comunitário na transposição da diretiva.

O artigo $4 .^{\circ}$ da Diretiva estabelece a impossibilidade dos Estados-membros de, na sua transposição, "manterem ou introduzirem no direito nacional disposições divergentes das previstas na presente Diretiva, nomeadamente disposições mais ou menos estritas que tenham por objetivo garantir um nível diferente de proteção do viajante”.

A introdução deste artigo $4 .^{\circ}$ alterou o paradigma que existia na anterior Diretiva, de harmonização mínima ${ }^{17}$, para o atual figurino de harmonização máxima, conforme tem vindo a ser comum em Diretivas com fortes preocupações de proteção do consumidor.

O legislador deixou apenas de fora desta preocupação de harmonização máxima, no disposto artigo 13. ${ }^{\circ}$, n. ${ }^{\circ}$ 1, segundo parágrafo, no qual abre a porta para os Estados-Membros alterarem a regra da responsabilidade civil pela execução da viagem, que recai sobre o organizador, podendo as legislações nacionais "manter ou introduzir disposições no direito nacional segundo as quais o retalhista também seja responsável pela execução da viagem organizada”.

Esta exceção à harmonização máxima é, ela própria limitada, porquanto a Diretiva vincula o legislador nacional na opção a tomar, tendo este apenas a opção de, através da legislação que aprovar, tornar responsável não só o organizador mas também o retalhista.

Embora o artigo 288..$^{\circ}$ do Tratado sobre o Funcionamento da União Europeia prescreva que "a Diretiva vincula o Estado-Membro destinatário quanto ao resultado a alcançar, deixando, no entanto, às instâncias nacionais a competência quanto à forma $e$ aos meios”, em áreas como o direito do consumo tem-se assistido a um movimento de aumento do nível de harmonização na transposição das regras entre os Estados-membros, que acaba por subverter a definição deste instrumento legislativo da União, transformando estas diretivas praticamente em regulamentos.

\footnotetext{
${ }^{16}$ Vid. Assens, C. A Gestão das redes- teçer laços sociais para o bem-estar económico,Lisboa,Piaget,2014.

${ }^{17}$ GUTMAN, Kathleen, The Constitution Foundations of European Contract Law: A Comparative Analysis, Oxford University Press, 2014, p. 48.
} 
No que toca ao direito do consumo, a Comunicação da Comissão ao Conselho e ao Parlamento Europeu sobre o Direito Europeu dos Contratos ${ }^{18}$ e a Comunicação da Comissão ao Parlamento Europeu, ao Conselho, ao Comité Económico e Social e ao Comité das Regiões Estratégia da Política dos Consumidores para 2002-2006, marca o início do movimento de harmonização máxima, estabelecendo, nomeadamente, que "o desenvolvimento da política dos consumidores ao nível da UE é o corolário indispensável do estabelecimento progressivo do mercado interno. A livre circulação de bens e serviços tornou necessária a adoção de regras comuns, ou pelo menos convergentes, para assegurar simultaneamente uma proteção suficiente dos interesses dos consumidores e a eliminação dos obstáculos regulamentares e das distorções da concorrência... Isto implica passar da atual situação, caracterizada pela existência de diferentes quadros normativos em cada EstadoMembro, para um ambiente mais coerente para a defesa do consumidor em toda a UE. ${ }^{19}$ ",

A doutrina de harmonização máxima tem como base legal o artigo $114 .^{\circ}$ do Tratado de Funcionamento da União Europeia $(\mathrm{TFUE})^{20}$, que prevê aproximação das legislações na prossecução das medidas destinadas a estabelecer o mercado interno e/ou a regular o seu funcionamento, conforme plasmado no artigo $26 .^{\circ}$ do TFUE, e pretende assegurar um nível de proteção elevado em matérias de saúde, segurança, proteção do ambiente e defesa dos consumidores.

A harmonização máxima teve como pontos altos a Diretiva relativa a práticas comerciais desleais (2005/29/CE), a Diretiva de crédito ao consumo (2008/48/CE), a Diretiva de timeshare (2008/122/CE) e a Diretiva relativa aos direitos dos consumidores (2011/83/UE).

A utilização das normas de harmonização máxima nas diretivas tem sido defendida pela Comissão ${ }^{21}$, com os argumentos seguintes: em primeiro lugar, o facto de existirem normas divergentes, entre as legislações nacionais, sobre as mesmas matérias, poderá prejudicar o desenvolvimento dos mercados internos, criando significativas barreiras que afetam os negócios e os consumidores; defende, por outro lado, que a harmonização mínima pode ter como efeito a fragmentação do quadro normativo da União; a harmonização máxima é vista, também, com forma de contribuir para elevar o nível de certeza e segurança jurídica, quer de consumidores quer de investidores, conseguindo atingir um correto equilíbrio entre a defesa dos interesses dos consumidores e dos empresários; por fim, tem sido defendido que, em temas de direito do consumo, a harmonização máxima cria um nível mais elevado de proteção dos direitos dos consumidores. ${ }^{22}$.

\footnotetext{
${ }^{18}$ Comunicação da Comissão ao Conselho e ao Parlamento Europeu sobre o direito europeu dos contratos, Bruxelas, 11.07.2001, COM.

${ }^{19}$ Comunicação da Comissão ao Parlamento Europeu, ao Conselho, ao Comité Económico e Social e ao Comité das Regiões Estratégia da Política dos Consumidores para 2002-2006, JO, C 137 de 8.6.2002, p.2.

20 Vid. TWIGG-FLESNER, C., “Good-Bye Harmonization by Directives, Hello Cross-Border only Regulation?" - A way forward for EU Consumer Contract Law”, http://ec.europa.eu/justice/news/consulting_public/0052/contributions/309_en.pdf

${ }^{21}$ Argumentos invocados a propósito da Diretiva relativa aos direitos dos consumidores.

${ }^{22}$ SMITS, Jan, "Full Harmonization of Consumer Laws? A Critique of the Draft of the Directive on Consumer Rights”, European Revue of Private Law, 1-2010, Kluver Law International BV, Great Britain, p.7.
} 
Em resposta a estes argumentos, entende-se que, se é certo que os Eurobarómetros 320 e 321 de $2011^{23}$, indicam uma maior preocupação dos agentes económicos com o efeito negativo que a diversidade legal tem nas transações transnacionais ${ }^{24}$, também é certo, conforme considera Smits ${ }^{25}$, que esta diversidade legal, no que toca à maior parte dos ramos do direito, não tem influência significativa relativamente ao desenvolvimento dos mercados internos e ao estímulo das transações transfronteiriças.

Com efeito, para o autor existem outros fatores como a "língua, cultura, distância e diferença de normas técnicas” que têm bastante maior importância para os investidores e consumidores que propriamente a regulamentação de ramos do direito como o de consumo e que, ainda que existam áreas do direito da União cuja maior ou menor harmonização tenha impacto junto dos destinatários nacionais das normas, tal aconteceria sempre em ramos como o direito processual e o tributário e não em áreas como o do direito do consumo.

Por outro lado, o argumento da maior fragmentação dos regimes em casos de harmonização mínima é também contestado por Smits ${ }^{26}$, alegando que o direito aplicado pelos Estados-Membros e utilizado quer pelos empresários quer pelos consumidores é o direito nacional, no qual as diretivas são transpostas, e aí o direito do consumidor, ainda que fortemente harmonizado, é apenas uma pequena parte dos ordenamentos jurídicos nacionais, o que leva a que, de qualquer forma, exista fragmentação pela aplicação de normas de direito interno que nada têm que ver com as diretivas.

Tendo em conta este argumento, a União Europeia tem vindo a estabelecer a regra da harmonização máxima das várias diretivas que vão sendo aprovadas com influência no direito do consumidor, como é o caso da relativa às viagens organizadas e serviços conexos, onde adotou uma formulação legal, no artigo $4 .^{\circ}$, decalcada do artigo com o mesmo número da Diretiva relativa aos direitos dos consumidores. Igualmente, no art. $^{\circ} 23^{\circ}$, afirma a imperatividade da diretiva, seja aos organizadores, facilitadores ou prestadores de serviços de viagens organizadas ou conexos ( $\left.{ }^{\circ} 1\right)$, seja aos viajantes (n. ${ }^{\circ}$ s 2 e 3 ).

Por último, o argumento da defesa dos consumidores tem a fragilidade da harmonização máxima não constituir um meio suficiente para garantir uma maior proteção dos consumidores. A harmonização tornará, quanto muito, a proteção mais homogénea. Existirão sempre Estados-Membros com níveis de proteção do consumidor mais elevados e que, pela harmonização das normas, vão necessariamente ter que implementar novas regras que impliquem graus de proteção inferior ${ }^{27}$.

Ainda que sob a senda da harmonização mínima, a transposição de Diretivas tem sempre como ponto de chegada os fins a que o diploma obriga, ainda que como norma de mínimos. Tal pode constituir meio suficiente para atingir os fins a que se propõe a Comissão, ao defender a harmonização máxima, não impedindo, porém, que a norma nacional vá além das regras previstas na Diretiva na defesa de direitos como os de consumo.

\footnotetext{
${ }^{23}$ http://ec.europa.eu/public_opinion/archives/ebs/ebs_321_en.pdf

${ }^{24}$ SANTOS, José Augusto Cerqueira, A Harmonização do Direito do Consumo - Recentes desenvolvimentos ao nível europeu e nacional, Porto, Faculdade de Direito, 2015, Tese de Mestrado, p.18.

${ }^{25}$ Ob. Cit., p.18.

${ }^{26}$ Ob. Cit. ,p.18

${ }^{27}$ SMITS, Jan, Ob.Cit. p.8 e 9
} 
Os argumentos aduzidos sobre a harmonização máxima a propósito da Diretiva relativa aos consumidores têm óbvio cabimento quando se analisa a Diretiva relativa a viagens organizadas e serviços de viagem conexos. Por um lado, conforme já referido supra, ambas as normas têm igual formulação; por outro pretendem proteger idênticos bens jurídicos, porquanto foi a forte preocupação na defesa do mercado interno e do investimento transfronteiriço e a proteção dos consumidores que motivaram a existência e redação do artigo 4. ${ }^{\circ}$ da Diretiva em análise ${ }^{28}$. Na sua aplicação à Diretiva, procedem também os argumentos aduzidos supra que colocam em causa o mérito absoluto da harmonização máxima.

O legislador utilizou, aliás, estes argumentos nos considerandos da diretiva, afirmando que "importa harmonizar os direitos e as obrigações decorrentes dos contratos relativos a viagens organizadas e serviços de viagem conexos, a fim de criar um verdadeiro mercado interno dos consumidores nesse domínio, estabelecendo o bom equilíbrio entre um elevado nível de defesa do consumidor e a competitividade das empresas" (Considerando 5) e que "as disparidades entre as regras de proteção dos viajantes nos diferentes Estados-Membros desencorajam os viajantes de um Estado-Membro de adquirir viagens organizadas e serviços de viagem conexos noutro Estado-Membro e, paralelamente, desincentivam os organizadores e retalhistas de um Estado-Membro de vender esses serviços noutro Estado-Membro." (Considerando 6).

De facto, conforme exposto supra, não nos parece que a existência de um mercado interno e o investimento transfronteiriço fique, com a aplicação das novas regras, bastante mais protegido ou especialmente favorecido. Não cremos que, no caso desta Diretiva, esta relação seja causal, até porque tendo o turismo como elemento nuclear a deslocação de pessoas de um local para outro, grande parte das vezes fora do seu país de origem, não nos parece que a harmonização máxima das regras da viagem seja o catalisador do investimento ou da decisão de viajar.

Por outro lado, a Diretiva é reconhecidamente pobre quanto à sua técnica legislativa, muitas das suas normas são pouco claras e confusas, constituindo regras pouco operativas ${ }^{29}$. Aliás, os considerandos da Diretiva são bastante mais completos e explicativos que a parte dispositiva do diploma.

Apresentamos apenas um exemplo relativamente à transposição para o ordenamento jurídico português:

O artigo 12. ${ }^{\circ}$, n. ${ }^{\circ} 1$ da Diretiva prevê o direito do viajante de, em qualquer altura antes do início da viagem organizada, rescindir o contrato, podendo, no entanto, "ser obrigado a pagar ao organizador uma taxa de rescisão adequada e justificável”. Ao integrar o conceito impreciso "adequada”, o legislador da União considerou que, sendo as taxas, normalizadas e previstas nos contratos, consideram-se razoáveis, as "baseadas na antecedência da rescisão do

contrato relativamente ao início da viagem organizada e nas economias de custos e nas receitas esperadas em resultado da reafetação dos serviços de viagem” ou, quando não estiver prevista no contrato, "o montante da taxa de rescisão corresponderá ao preço da viagem organizada deduzido das economias de custos e das receitas resultantes da reafetação dos serviços de viagem”.

\footnotetext{
${ }^{28}$ GUTMAN, Kathleen, Ob. Cit.

${ }^{29}$ O volume das críticas é tal que, atualmente, a grande maioria das empresas de turismo alemãs, bem como a associação representativa dos agentes de viagens "DRV Deutscher Reiseverband”, exigem a alteração da Diretiva.
} 
Não cremos que desta regra consigamos retirar qualquer critério operacional que permita ao operador calcular a taxa de rescisão a cobrar ao viajante, que exerça o seu direito de rescisão, e que possa ser por aquele justificada perante este, obrigação que é imposta pela norma, in fine.

A deficiente técnica legislativa, a que a tradução portuguesa da norma não ajuda, prejudica quer o empresário que tem que encontrar na norma um critério operativo, claro e justificável que lhe permita exigir ressarcimento do investimento realizado naquela viagem organizada em concreto, bem como o consumidor que tem que aí obter uma regra para aferir da bondade da taxa de rescisão que lhe é cobrada.

A atual lei que disciplina em Portugal as viagens organizadas, o Decreto-Lei $\mathrm{n}$. 61/2011,como alterado pelo 199/2012, de 24 de agosto, adiante designado LAVTP, já prevê o direito de rescisão do cliente, estabelecendo no seu artigo $26 .^{\circ}$ que "o cliente pode rescindir o contrato a todo o tempo, devendo a agência reembolsá-lo do montante antecipadamente pago, deduzindo os encargos a que, comprovadamente, o início do cumprimento do contrato e a rescisão tenham dado lugar e uma parte do preço do serviço não superior a 15\%”.

Parece-nos que esta norma comporta um critério claro e operativo que permite encontrar uma forma de compensar o empresário pelos danos efetivos que lhe causa o exercício do direito de rescisão por parte do cliente para que ambas as partes contratuais consigam ver os seus interesses protegidos. Temos sérias dúvidas que uma norma com as características da atualmente existente possa subsistir na transposição da Diretiva, uma vez que a harmonização máxima impede que seja estabelecido um critério diverso do previsto no diploma.

Para além do exemplo dado, pensamos que a harmonização máxima imposta pela Diretiva irá trazer dificuldades na transposição de várias outras normas constantes da Diretiva, nomeadamente quanto a questões fundamentais para o funcionamento do seu regime, como a definição legal de viagem organizada, de serviços conexos de viagem, e a distinção entre ambos os institutos ${ }^{30}$, por serem noções bastante vagas, opacas e com distinções baseadas em critérios nada operacionais ${ }^{31}$.

Em suma, entendemos que o nível de harmonização máxima tal como exigido pela Diretiva, mais do que visando a protecção uniforme dos direitos dos viajantes no espaço comunitário, mais do que sendo um regime eficaz indutor do investimento e do mercado interno, visa efectivamente criar uma oferta empresarial, veremos, digital de viagens e turismo padronizada a nível comunitário baseada no valor e na produção de informação. Adiante descreveremos outras formas de padronização e uniformização que apontam no mesmo sentido.

\footnotetext{
${ }^{30}$ Matéria que não aprofundaremos mais, por não fazer parte do tema em estudo, e que é bastante mais aprofundada por outros autores no decurso da presente publicação.

${ }^{31}$ Como o critério da transmissão, pelo operador com quem é celebrado o contrato, dos dados pessoais do viajante aos restantes operadores, sendo celebrado o contrato com o último no prazo máximo de 24 horas após a confirmação da reserva do primeiro serviço de viagem, para a caracterização como viagem organizada, previsto no artigo $3 .^{\circ}$, n. $^{\circ}$ 2, alínea b), v) da Diretiva.
} 


\section{OS SUJEITOS CONTRATUAIS}

A disciplina dos sujeitos (o quem entre sujeitos no contrato de viagem organizada e de serviços conexos) foi também bastante alterada aparecendo agora uma nova nomenclatura de sujeitos, com um regime distinto.

\subsection{A Procura - O Viajante.}

A Diretiva estabelece no seu artigo 3. ${ }^{\circ}$, n. ${ }^{\circ} 6$ que é viajante: “Qualquer pessoa que procure celebrar um contrato ou esteja habilitada a viajar com base num tal contrato, no âmbito da presente Diretiva”.

Apesar de, conforme analisado supra, uma das maiores preocupações da presente Diretiva ser a proteção do consumidor, o único local onde o legislador utiliza a palavra “consumidor” é no artigo $10^{\circ}$ da Diretiva, ao declarar a sua preocupação na elevada defesa dos seus direitos. Em toda a Diretiva, a pessoa que celebra ou pretende celebrar um contrato de viagem a um profissional que comercialize serviços de viagem é denominada viajante.

Em todo o "acquis" de direito do consumidor, este é caracterizado por ser uma pessoa singular. A relação de consumo protegida pelo direito comunitário é sempre B2C (business to consumer). Tal sucede na generalidade das fontes normativas de direito da União, bem como tem sido decidido de forma clara pelo TJUE ${ }^{32}$.

A única diretiva onde tal não sucedia era na anterior Diretiva relativa a viagens organizadas $^{33}$, onde, no seu artigo $2 .^{\circ}$, n. ${ }^{\circ} 4$, era considerado consumidor:

“A pessoa que adquire ou se compromete a adquirir a viagem organizada («o contratante principal») ou qualquer pessoa em nome da qual o contratante principal se compromete a adquirir a viagem organizada («os outros beneficiários») ou qualquer pessoa a quem o contratante principal ou um dos outros beneficiários cede a viagem organizada («o cessionário»)».

Nesta norma é considerado consumidor quem celebra um contrato de viagem organizada, sendo, por esse facto objetivo, considerado uma parte mais frágil com necessidade de proteção, no âmbito das normas de defesa do consumidor ${ }^{34}$.

\footnotetext{
32 e.g Ac. Benicasa Dentakit, srl, C-269/95, onde, a propósito de um conflito de competência territorial, pela aplicação de um pacto de aforamento, foi declarado pelo TJUE que “... a fim de determinar a qualidade de consumidor de uma pessoa, conceito que importa interpretar de forma restritiva, há que atender à posição dessa pessoa num contrato determinado, em conjugação com a natureza e finalidade deste, e não à situação subjetiva dessa mesma pessoa... Por conseguinte, só os contratos celebrados com o objetivo de satisfazer as próprias necessidades de consumo privado de um indivíduo ficam sob a alçada das disposições que protegem o consumidor enquanto parte considerada economicamente mais débil. A proteção especial que essas disposições pretendem assegurar não se justifica com casos de contratos cujo objetivo é uma atividade profissional, ainda que futura, dado que o carácter futuro de uma atividade nada retira à sua natureza profissional.” Esta é, aliás, a conceção que subjaz à generalidade dos acórdãos de proteção ao consumidor em que se considera este como parte especialmente frágil no seio da relação de consumo, meramente a título exemplificativo, Ac. Dirk Frederic Asbeek Brusse, C- 488/11.

${ }^{33}$ Working Document on the Council Directive 90/314/EEC of 13 June 1990 on package travel, package holidays and package tours, 26.07.2007, Brussels, http://ec.europa.eu/consumers/archive/rights/commission_working_document_final26-07-2007.pdf. p. 7 e Consumer Protection in the EU, Policy Overview, EPRS European Parliamentary Research Service, Jana Valant, September 2015, p.4.
} 
Esta noção lata de consumidor adotada na anterior Diretiva das viagens organizadas não era uma opção pacífica, tendo, inclusivamente, alguns ordenamentos jurídicos ${ }^{35}$ adotado a designação de viajante em detrimento da noção de consumidor que estava prevista na norma da União Europeia, entendimento que foi o adotado na nova Diretiva.

Por outro lado, o relatório do Livro Verde sobre a revisão do acervo relativo à defesa do consumidor ${ }^{36}$ vem tomar posição relativamente à utilização de critérios para caracterizar a figura do consumidor, afirmando que "considera essencial a necessidade de definir como "consumidor" qualquer pessoa singular que aja com finalidades que não se enquadrem no âmbito da sua atividade profissional”. Considera-se que o critério correto para a definição de consumidor é o da "abordagem negativa da finalidade do acordo", ou seja, é consumidor quem não prossiga, na relação jurídica, um fim que se enquadre na atividade profissional.

O relatório afirma que "o afastamento sistemático das pessoas coletivas deste conceito justifica-se pelo objetivo de clareza que se pretende”, sendo o critério acima exposto o mais objetivo.

Com a adoção deste critério, afastam-se, sempre, as pessoas coletivas do conceito de consumidor $^{37}$, já relativamente às pessoas singulares, dependerá sempre do fim que estas pretenderem prosseguir na relação jurídica. A aplicação deste critério afasta, por outro lado, a análise de realidades como, entre outras, a atividade da empresa e a sua dimensão.

Subsistia, no entanto, a questão de saber se, no âmbito da nova Diretiva, existe a mesma necessidade de proteção do adquirente de viagens organizadas que, por um lado, seja uma pessoa coletiva e, por outro, ainda que não tenha esta natureza legal, adquira a viagem com um fim profissional.

O documento de trabalho do Conselho, de 2007, sobre a Diretiva 90/314/EC, após reconhecer o sentido dominante em que o "acquis" define consumidor, refere que, relativamente ao instrumento legislativo em análise, a mera exclusão deste conceito das pessoas coletivas ou das que, ainda que singulares, tenham como objetivo de viagem o exercício da sua atividade profissional, deixaria desprotegidos uma enorme fatia de adquirentes de viagens, apenas pela sua natureza jurídica ou pelo fim a que a mesma se

\footnotetext{
${ }^{34}$ BAR, Von C. et all, Towards a European Civil Code, Second Revised and Expanded Edition, HARTKAMP, A et all (Eds.), Kluwers Law International, The Hague/London/ Boston, 1998, p. 144; TORRES LANA, J, Derechos y Garantías del Contratante y del Usuário de Serviços Turisticos Adquiridos Online, Nuevas fórmulas de comercialización online de servicios turísticos: subsunción en los tipos legales y distribución de responsabilidad, PANIZA A. (Eds.), Editorial Comares, Granada, 2013, p. 22 e Working Document on the Council Directive 90/314/EEC of 13 June 1990 on package travel, package holidays and package tours, 26.07.2007, Brussels, http://ec.europa.eu/consumers/archive/rights/commission_working_document_final26-072007.pdf.

${ }^{35}$ É o caso da Dinamarca e da Áustria, BAR, Von C. et all, Towards a European Civil Code, Second Revised and Expanded Edition, HARTKAMP, A et all (Eds.), Kluwers Law International, The Hague/London/ Boston, 1998, p. 144.

36 Relatório referente ao Livro Verde sobre a revisão do acervo relativo à defesa do consumidor (2007/2010(INI)) Comissão do Mercado Interno e da Proteção dos Consumidores, relatora Beatrice Patrie,16.07.2007, p.7, http://www.europarl.europa.eu/sides/getDoc.do?pubRef=//EP//NONSGML+REPORT+A6-2007-0281+0+DOC+PDF+V0//PT

${ }^{37}$ Por aplicação do princípio da especialidade das pessoas coletivas, em Portugal, previsto no artigo $160 .^{\circ}$ do Código Civil.
} 
destina, ao que acresce a dificuldade em caracterizar e saber que regime aplicar às transações de uso misto, nas quais a viagem tem ambos os objetivos, trabalho e lazer ${ }^{38}$.

Conforme afirma Torres Lana ${ }^{39}$, o "turista” é sempre uma pessoa singular, ainda que a viagem tenha sido contratada por uma pessoa coletiva e é sobre quem efetivamente viaja que recaem as necessidades de proteção jurídica. É o viajante que, em primeira instância, sofre os danos efetivos advenientes dos problemas que possam surgir na viagem.

Nasce assim a opção de denominar "quem”, no âmbito do regime da nova Diretiva, adquire uma viagem organizada ou um serviço conexo. A denominação "viajante”, de forma a, deixando de aplicar-se a expressão "consumidor", sentido hoje unanime no direito da União, reconhecer-se, ainda assim, que outras pessoas jurídicas, que atuam no âmbito da sua atividade profissional, necessitam de uma proteção equiparável aos consumidores.

Esta proteção atribuída pela Diretiva não se aplica, porém, a todas as pessoas coletivas. O artigo 2. ${ }^{\circ}$, n. ${ }^{\circ}$ 2, alínea c) da Diretiva exclui expressamente do seu âmbito de aplicação as "viagens organizadas e serviços de viagem conexos adquiridos com base num acordo geral para a organização de viagens de negócios entre um operador e outra pessoa singular ou coletiva que atue para fins que se insiram no âmbito da sua atividade comercial, empresarial, artesanal ou profissional”.

Esta norma exclui da proteção da Diretiva o viajante profissional, que, para o legislador da União necessitava de proteção quando adquiria e realizava uma viagem organizada ou um serviço de viagem conexo, quando existe um instrumento contratual geral que regule as viagens entre aquele profissional e o operador.

Temos dificuldade em entender a ratio da norma. A justificação do legislador é a de evitar o excesso de regulação ${ }^{40}$ na mesma viagem, a qual tendo por base um contrato geral para a sua comercialização, não necessita da mesma proteção jurídica que as que não tenham tal instrumento jurídico por base. Defende ainda o legislador que tal norma não coloca em causa a proteção das pequenas e micro empresas, que são consideradas viajantes.

Não cremos que a aplicação das normas decorrentes da Diretiva a uma viagem que tenha por base um contrato geral entre o operador e um profissional resulte em excesso de regulamentação. Não vemos que tal seja diferente da possibilidade de alguém celebrar, com um operador, um contrato geral que regule a realização de viagens que não tenham fins profissionais, situação que indubitavelmente, recai no âmbito de proteção da Diretiva.

Se pensarmos, assim, numa deslocação de um docente de uma universidade, que seja parte num contrato geral para a aquisição de viagens em trabalho dos seus funcionários, a um congresso científico fora do país, não conseguimos perceber qual a diferença, a nível de necessidade de proteção do viajante, desta relação jurídica relativamente a outra em que o contrato geral não tenha sido celebrado.

Não encontramos, ainda, na norma qualquer limitação da dimensão da empresa ou profissional que permita afirmar existir uma proteção das pequenas e micro empresas. Esta

\footnotetext{
${ }^{38}$ Working Document on the Council Directive 90/314/EEC of 13 June 1990 on package travel, package holidays and package tours, 26.07.2007, Brussels, http://ec.europa.eu/consumers/archive/rights/commission_working_document_final26-07-2007.pdf.

39 TORRES LANA, J, Ob.Cit. p. 24.

40 Denominado por “overregulation” pela Comissão na apresentação da Diretiva, http://ec.europa.eu/consumers/consumer_rights/travel/package/index_en.htm.
} 
referência aparece apenas no considerando 7, não constando da parte dispositiva do diploma. Não se pode, por outro lado, presumir que apenas as médias e grandes empresas celebram contratos gerais com operadores que regulem as viagens dos seus profissionais, aliás frisando a norma a sua aplicação a pessoas singulares e aos casos de uma atividade artesanal, onde normalmente há um maior número de pequenas e micro empresas, não se entende esta justificação num documento oficial na Comissão ${ }^{41}$.

Em suma, a evolução do conceito de consumidor para viajante e as restrições constantes do âmbito de aplicação desta noção na Diretiva, não apontam para maiores e melhores desenvolvimentos no plano da sua protecção uniforme no mercado interno das viagens e turismo. Veremos, pelo contrário, que as noções na Diretiva no lado da oferta sofreram grandes transformações e que vão contribuir para a resposta afirmativa ao problema de investigação colocado.

\subsection{A Oferta - O Operador-Organizador e retalhista.}

O operador é "qualquer pessoa singular ou coletiva, pública ou privada, que, nos contratos abrangidos pela presente Diretiva, atue, inclusive através de outra pessoa que atue em seu nome ou por sua conta, para fins relativos à sua atividade comercial, empresarial, artesanal ou profissional, quer atue como organizador, retalhista, operador que facilita serviços de viagem conexos ou como prestador de um serviço de viagem” (art. ${ }^{\circ} 3 .^{\circ}$ n. ${ }^{\circ}$ ).

No fundo, qualquer ator que exerça a sua atividade empresarial no lado da oferta, seja entidade pública ou privada, de natureza empresarial, artesanal ou profissional e esteja inserida, por alguma razão, nos serviços oferecidos ao viajante de viagem organizada ou serviços de viagem conexos é um operador.

Quanto à denominação, parecem-nos bastante mais felizes outras versões da Diretiva, como a inglesa, que utiliza a expressão "trader", a francesa com "profissionnel" ou espanhola com a designação “empresario”. A palavra "operador” tem usualmente, no turismo, um significado muito específico, identificando um dos principais atores da cadeia de distribuição da viagem, o operador turístico (tour operator). Parece-nos, assim, que a utilização da expressão operador para caracterizar qualquer interveniente, no lado da oferta, que intervenha numa viagem organizada ou serviço de viagem conexo é equívoca e torna a interpretação confusa.

Dentro da categoria de operador a lei distingue dois tipos de operadores, o organizador e o retalhista (art. ${ }^{\circ} 3 .^{\circ}$ n. ${ }^{\circ}$ s $8^{\circ}$ e n..$^{\circ}$ 9). É de destacar, em primeiro lugar, o facto de se optar pela clássica distinção entre organizador/grossista, por um lado e retalhista, por outro. Tal distinção já existia na anterior Diretiva, na qual eram designados, na tradução portuguesa, por agência e organizador. Sucede que, sendo o anterior diploma uma norma de harmonização mínima, os Estados-Membros não estavam obrigados a transpor tal distinção.

A distinção entre operadores é agora, em virtude do regime de harmonização máxima e obrigatória, aquando da transposição da Diretiva.

No entanto, a própria Diretiva trata a distinção de forma fluída ao afirmar no considerando 22:

\footnotetext{
${ }^{41}$ http://ec.europa.eu/consumers/consumer_rights/travel/package/index_en.htm.
} 
"Determinar se um operador age na qualidade de organizador de uma determinada viagem organizada deverá depender da sua participação na organização da viagem em causa, e não da forma como descreve a sua atividade. Para determinar se um operador é um organizador ou um retalhista, deverá ser indiferente que o operador intervenha no lado da oferta ou se apresente como um agente que atua por conta do viajante. “

Assim, será organizador o operador que numa viagem específica “combine, venda ou proponha para venda viagens organizadas, diretamente, por intermédio de outro operador ou conjuntamente com outro operador, ou o operador que transmite os dados do viajante a outro operador, nos termos do ponto 2, alínea b), subalínea v)” e será retalhista quem, numa viagem em concreto, não atuando enquanto organizador, que "venda ou proponha para venda viagens organizadas combinadas por um organizador" (art. ${ }^{\circ} 3^{\circ} \mathrm{n}^{\circ} 7^{\circ}$ e n. ${ }^{\circ} 8$ ).

A distinção entre estes operadores é aferida em concreto, atendendo à sua atuação e o papel desempenhado na viagem em análise e, não de forma abstrata, tendo em conta, por exemplo, a descrição feita, por qualquer forma, da sua atividade.

Podemos, assim, ter como organizadores ou retalhistas "operadores" com atividades variadas, os quais poderão atuar quer no lado da oferta, quer enquanto agente por conta do viajante. Serão retalhistas se apenas comercializarem a viagem organizada por outrem e serão organizadores se organizarem e combinarem serviços turísticos e/ou os vendam ou proponham para venda a retalhistas.

Podemos, inclusivamente, ter empresas turísticas que atuam em determinadas viagens como organizadores e noutras como retalhistas ou se tivermos, como exemplo, uma agência de viagens e turismo na vertente de incoming, esta poderá ser considerada um organizador, se nomeadamente organizar um grupo e o comercializar junto de outro profissional intermediário ou diretamente junto de um cliente final ou apenas um operador se, como também faz parte da sua atividade habitual, apenas fornecer ao organizador um produto turístico $^{42}$ com o qual este compõe a viagem organizada.

A Diretiva deixou de prever a existência da agência de viagens e turismo, qualificação legal tradicional da empresa turística que, durante muitos anos, foi a base da distribuição nas viagens turísticas e de grande parte dos serviços que as compunham.

A comercialização das viagens e de produtos turísticos esteve, tradicionalmente, ligada às atividades desenvolvidas, a título principal ou acessório, pelas agências de viagens. De facto, a, ainda em vigor, lei portuguesa das agências de viagem (LAVTP) prevê duas listagens de atividades, sendo uma, designada por "atividades próprias” 43 , as quais estão limitadas ao princípio da exclusividade, apenas podendo ser exercidas, em território nacional, por agências de viagem, nos termos do disposto no artigo $4 .^{\circ}$, n. $^{\circ} 1 .^{44}$ e outra que elenca atividades

\footnotetext{
42 e.g. o alojamento.

${ }^{43}$ A saber: “a) A organização e venda de viagens turísticas; b) A representação de outras agências de viagens e turismo, nacionais ou estrangeiras, ou de operadores turísticos nacionais ou estrangeiros, bem como a intermediação na venda dos respetivos produtos; c) A reserva de serviços em empreendimentos turísticos; d) A venda de bilhetes e reserva de lugares em qualquer meio de transporte; e) A receção, transferência e assistência a turistas."

${ }^{44}$ Este princípio da exclusividade é, neste diploma, mitigado com as exclusões previstas nos artigos $3 .^{\circ}$, n. ${ }^{\circ} 3$ e $4 .^{\circ}, n^{\circ} 2$.
} 
desenvolvidas pela agência de viagens a título acessório ${ }^{45}$, relativamente às quais não se aplica a regra da exclusividade.

Parece-nos que, tendo em conta a regra da harmonização completa, tal regime não poderá subsistir na transposição da Diretiva. Esta abre o espectro da atividade de operador a qualquer pessoa jurídica, no sentido amplíssimo exposto no seu artigo $3 .^{\circ}$. n. ${ }^{\circ}$. Assim, qualquer ente dotado de personalidade jurídica que comercializar um qualquer serviço turístico pode ser considerado operador, sendo que a posterior classificação entre organizador e retalhista depende apenas da atividade que, na prática exerce e de como a exerce, e não de qualquer qualificativo legal, não sendo assim possível limitar legalmente tais atividades a um tipo de operador ou atribuí-las de forma exclusiva, como até aqui foi feito ${ }^{46,47}$.

Esta quebra do princípio da exclusividade no acesso à atividade de organização e distribuição na venda de viagens organizadas representa a grande alteração estrutural na regulação do mercado das viagens e turismo comunitário. Na verdade, no atual mundo digital em rede das tecnologias de informação e comunicação à distância e da Internet, os efeitos descentralizadores ultrapassaram os efeitos centralizadores ${ }^{48}$, estando o valor da informação sujeito a um intenso valor e competição na sua produção e divulgação, pelo que se sujeita o mesmo a um princípio de livre concorrência.

Cria-se, assim, um novo tipo de ofertante, seja ele de natureza pública ou privada na organização, venda e divulgação da viagem e serviço turistico, a que designaríamos, como "operador” em turismo (para não confundir com a expressão "operador turistico”) e que vai participar uniformemente, tal como um "operador em rede", seja como produtor, seja como distribuidor, nas faculdades e responsabilidades abertas pelo valor da informação, sua comunicação, organização e intermediação na venda de serviços em turismo ${ }^{49}$.

\footnotetext{
${ }^{45}$ A saber: “a) A obtenção de certificados coletivos de identidade, vistos ou outros documentos necessários à realização de uma viagem; b) A organização de congressos e de eventos semelhantes; c) A reserva e a venda de bilhetes para espetáculos e outras manifestações públicas; d) A realização de operações cambiais para uso exclusivo dos clientes, de acordo com as normas reguladoras da atividade cambial; e) A intermediação na celebração de contratos de aluguer de veículos de passageiro sem condutor; f) A comercialização de seguros de viagem e de bagagem em conjugação e no âmbito de outros serviços por si prestados; g) A venda de guias turísticos e de publicações semelhantes; h) $\mathrm{O}$ transporte turístico efetuado no âmbito de uma viagem turística, nos termos definidos no artigo 15. ; i) A prestação de serviços ligados ao acolhimento de turistas, nomeadamente a organização de visitas a museus, monumentos históricos e outros locais de relevante interesse turístico.”

${ }^{46}$ Com exclusão para o regime do Decreto-Lei n. ${ }^{\circ}$ 198/93, de 27 de maio que afastou a distinção entre atividades próprias e acessórias, retomada em 1997 com a LAVT.

47 Esta alteração vem em linha com os regimes aprovados na Diretiva Bolkestein que simplificaram significativamente os regimes das atividades de prestação de serviços na União Europeia e tiveram um grande impacto nos regimes jurídicos dos prestadores de serviços turísticos nos Estados-Membros, nomeadamente quanto à constituição e legalização de agências de viagem e turismo, nomeadamente, através da eliminação do anterior licenciamento e a sua substituição por simples comunicação e inscrição no "Registo Nacional de Agencias de Viagem e Turismo” (RNAVT), com a consequente redução de emolumentos de €12.500 para $€ 1.500$, a possibilidade de exercício da atividade por pessoas singulares, eliminação da exigência de capital social de $€ 100.000,00$ e de requisitos como o da idoneidade comercial, entre outros.

${ }^{48}$ VID.Nyr,J.,O futuro do poder (trad. Luis Oliveira Santos (João Quina Edições) do original Future of Power), Lisboa, Circulo de Leitores,2010.

${ }^{49}$ Conforme assinalado por Machado, V. em Turismo, Direito e Democracia, Lisboa, Escolar Editora,2015.
} 


\section{PACOTES DINÂMICOS, VIAGENS ORGANIZADAS E SERVIÇOS CONEXOS.}

\subsection{O conceito de pacote dinâmico.}

Na economia em rede, impõe-se que o cliente entre na cadeia de valor do produtor e realize tarefas em seu lugar ${ }^{50}$ como forma de economizar e diminuir os custos de transação na negociação e venda de serviços. Que produtos são regulados na nova Diretiva? Responde-se ao segundo elemento sistémico da investigação (o quê- o objeto), seja, que contratos turísticos são ora regulados.

O pacote dinâmico, tal como foi sendo construído pela doutrina ${ }^{51,52}$, também tendo como ponto de partida, o conceito de viagem organizada na Diretiva de 1990 (art. ${ }^{\circ} .^{\circ}{ }^{\circ} .^{\circ} 1$ ) permite que os turistas possam construir o seu próprio pacote "à la carte", escolhendo o voo, hotel, excursões, transferes, aluguer de automóveis, viagens de comboio, seguro de viagem, entre outros, baseando-se, geralmente, na oferta de vários prestadores de serviços turísticos conectados diretamente via internet através de uma agência de viagens.

A primeira ideia a reter é a de que os computadores e, em especial, a Internet, em muito contribuíram para o surgimento do pacote dinâmico ${ }^{53}$. Com efeito, sem o advento da Internet não haveria pacote dinâmico, que permite que o turista possa, na calma da sua casa ou escritório, obter informações, tratá-las, escolher as suas preferências e, finalmente, contratar uma viagem ${ }^{54}$.

Importa afirmar claramente, nesta sede, que cada viagem contratada pela internet não é, só por isso, um pacote dinâmico. É igualmente possível contratar desta forma o pacote clássico, ou uma viagem "taylor made", razão pela qual a doutrina se empenhou em olhar para os elementos que caracterizam o pacote dinâmico e dar-lhe o seu próprio conceito, a que se atribuiu um determinado regime jurídico.

As características do pacote dinâmico, para ser considerado como tal em Portugal, eram e ainda são as seguintes:

\section{i. Ser vendido por uma agência de viagens}

Em Portugal, apenas os agentes de viagens podem vender viagens turísticas (art. ${ }^{\circ}$ 3. ${ }^{\circ} \mathrm{n}^{\mathrm{o}} 1$ alínea a) da LAVTP).

\footnotetext{
${ }^{50}$ Ob. cit, Assens, p.169.

${ }^{51}$ Cfr. Fullana, Antonia P., Nuevas tecnologías aplicadas al turismo y sus consecuencias jurídicas: los paquetes dinâmicos, Paquetes dinámicos de turismo: problemas y soluciones jurídicas desde una perspectiva internacional, Madrid: Ed. Dykinson, 2014

${ }^{52}$ Cfr. Vidal, João A., La responsabilidad de las empresas turísticas frente a la problemática de los paquetes dinámicos: el caso de Portugal, Paquetes dinámicos de turismo: problemas y soluciones jurídicas desde una perspectiva internacional, Madrid: Ed. Dykinson, 2014

${ }^{53}$ Cfr. Fullana, Antonia P., La protección del adquirente a distancia de servicios turísticos", en Revista de Derecho Privado , no 2 (marzo-abril 2012)

${ }^{54}$ Cfr. Café, Afonso Ribeiro, "Paquetes dinámicos y la transposición de la Directiva de servicios en Portugal (desde el punto de vista de los empresarios de turismo), em Paquetes dinámicos de turismo: problemas y soluciones jurídicas desde una perspectiva internacional (Dir. Paniza Fullana). Madrid: Ed. Dykinson, 2014.
} 
O conceito de "viagem turística" em Portugal corresponde a uma viagem integrada por dois dos três elementos seguintes: transporte; alojamento; serviços turísticos não subsidiários do transporte ou do alojamento. As viagens turísticas são divididas em dois grandes tipos: viagem organizada (ou em pacote); e viagem personalizada (ou taylor made). O pacote, de acordo com a lei portuguesa (art. ${ }^{\circ} 15 .^{\circ} \mathrm{n}{ }^{\circ}$ 2 da LAVTP), é aquele que é vendido a um preço "all inclusive", que deve prolongarse por mais de 24 horas ou incluir, pelo menos, uma pernoita. A viagem personalizada, como o nome indica, é preparada de acordo com exigências específicas dos clientes (art. ${ }^{\circ} 15^{\circ} \mathrm{n}^{\mathrm{o}} 3$ ).

ii. $\quad$ Permitir a recombinação automática (on-line) dos elementos da viagem, feita diretamente pelos turistas em tempo real

Todo o processo de criação de um pacote dinâmico tem que ser automático, o que significa que o consumidor pode explorar todas as combinações possíveis sem que essa ação produza efeitos jurídicos. Mas as combinações possíveis foram previamente determinadas pela agência de viagens ou operador turístico. Falamos, portanto, num número finito de combinações.

iii. $\quad$ O preço final ser dado após a construção do pacote, sem discriminação das parcelas que o compõem

Como supra referido, o pacote, de acordo com a referida lei portuguesa, é vendido por um montante fixo. Assim, quando se trata de um pacote dinâmico, uma das características essenciais é que seja vendido a um preço global, apenas visível no final do seu processo de construção.

iv. $\quad$ O contrato ser celebrado com a agência e não com os prestadores de serviços que, em concreto, prestam os serviços que compõem o pacote

Esta foi sempre, para nós, uma característica absolutamente essencial do conceito de pacote dinâmico. O contrato de fornecimento da viagem deve ser realizado entre o turista e a agência de viagens. Se o contrato for celebrado entre o consumidor/turista e o prestador final de um determinado serviço, por exemplo, um hotel ou um transfer, não se poderá falar de pacote dinâmico. Com efeito, a existência de intermediação é fundamental para o conceito. Como veremos adiante, a simples recombinação dos componentes de uma viagem não faz nascer, automaticamente, um pacote dinâmico, o que tem grandes reflexos em matéria de responsabilidade.

A questão da responsabilidade das agências de viagens é vasta e extremamente importante para a segurança do cliente/turista/viajante. Portanto, a chegada da Diretiva 90/314/CEE do Conselho, de 13 de junho de 1990, foi um marco de enorme importância para garantir o turista na sua jornada. No entanto, e embora a Diretiva tenha sido transposta para as diversas legislações nacionais, a verdade é que a proteção dada em cada Estado membro não foi a mesma ou não se materializou da mesma forma ${ }^{55}$.

Quanto à responsabilidade das agências de viagens na venda dos pacotes dinâmicos, este problema tinha, e continua a ter, uma solução clara. A sentença proferida no processo Garrido vs. Clube-Tour ${ }^{56}$ no Tribunal de Justiça na União Europeia decidiu que o conceito de

\footnotetext{
${ }^{55}$ Razão pela qual a nova Diretiva estabelece um padrão de harmonização com pouca liberdade para os Estados.

${ }^{56}$ Cfr. sentença no processo C-400/00, de 30 de Abril de 2002.
} 
"pacote" previsto no artigo 2, n. 1, da Diretiva 90/314 / CEE, relativa às viagens organizadas, deve ser interpretado como incluindo viagens organizadas por uma agência de viagens, a pedido do consumidor, ou um pequeno grupo de consumidores, de acordo com suas necessidades específicas ${ }^{57}$. É hoje pacífica esta interpretação do conceito de viagem organizada, ou em pacote, até porque aquele tribunal a vem utilizando sistematicamente em vários litígios.

Como decorrência lógica desta interpretação temos que, se a responsabilidade das agências de viagens se estende às viagens designadas por "taylor made", por maioria de razão deve entender-se que esta responsabilidade existe também nos pacotes dinâmicos, que são uma realidade mais próxima do conceito de viagem organizada. Assim, se um agente de viagens vende um pacote dinâmico em Portugal e houver qualquer falha ou cumprimento defeituoso por qualquer dos vários prestadores de serviços envolvidos, o cliente/turista pode demandá-lo pelos danos causados, sem prejuízo do direito de regresso que este tenha contra o infrator.

E se o pacote dinâmico fosse vendido por uma empresa que não era uma agência de viagens ou operador turístico?

Portugal tem resolvido este problema de forma direta: simplesmente não é permitido. Com efeito, a lei portuguesa ${ }^{58}$ é clara sobre esta questão, determinando que a comercialização de viagens turísticas é feita exclusivamente através de agentes de viagens ${ }^{59}$. Assim, todo o produto que incorpore dois dos três elementos previstos na lei (transporte, alojamento e serviços turísticos não subsidiários do transporte ou do alojamento) só pode ser vendido por uma agência de viagens. O pacote dinâmico está integrado, por natureza, neste conceito, pelo que não pode ser comercializado por uma entidade que não seja uma agência de viagens. Neste cenário, teremos uma questão clara de ilegalidade, que deve ser resolvida de acordo com as regras gerais relativas aos atos ilícitos e que são, em geral, as regras de direito civil sobre responsabilidade, seja ela contratual ou extracontratual ${ }^{60,61}$.

Como se sabe, o regime da responsabilidade civil contratual é mais protetor para o turista $^{62}$ do que o da responsabilidade extracontratual. Em primeiro lugar, pela inversão do ónus da prova: na responsabilidade contratual motivada pelo incumprimento de um contrato, o ónus da prova pertencerá ao prestador do serviço e não ao lesado. A segunda razão, pelo menos em Portugal, é a prescrição do direito: a prescrição na responsabilidade contratual é, regra geral, de 20 anos, enquanto na responsabilidade extracontratual é de apenas 3 anos.

\footnotetext{
${ }^{57}$ No mesmo sentido havia já decidido o tribunal Europeu nas sentenças Rechberger, de 15 de Junho de 1999, Proc. C-140/97, e AFS Intercultural Programs Finland, de 11 de Fevereiro de 1999, Proc. C237/97.

${ }^{58}$ Cfr. Decreto-Lei n. ${ }^{\circ}$ 61/2011, de 6 de maio, com a redação dada pelo Decreto-Lei n. ${ }^{0}$ 199/2012, de 24 de Agosto.

${ }^{59}$ Cfr. artigo $4^{\text {o }}$, n. ${ }^{\circ}$ 1, da Lei das Agências de Viagem.

${ }^{60}$ Cfr. Antunes Varela, João de Matos, Das Obrigações em Geral, Vol. I, Coimbra.

${ }^{61}$ Cfr. Cordeiro, António Menezes, Direito das Obrigações, $2^{\circ}$ Vol., Lisboa.

${ }^{62}$ E o turista/viajante reclama uma especial proteção, atentas as circunstâncias próprias de uma viagem, em que a deslocalização do sujeito e as normais dificuldades com idiomas estrangeiros e questões culturais se traduzem numa enorme vulnerabilidade, conforme refere Lana, Torres "La protección del turista en el ámbito jurídico privado", AA.VV., em La protección del turista como consumidor . Valencia: Ed. Tirant lo Blanc, 2003
} 
Para nós, e embora ilícito, existe um contrato entre as partes, pelo que a responsabilidade deverá ser contratual. Qualquer outro entendimento configuraria uma situação de abuso de direito, na modalidade de venire contra factum proprio.

A questão mais difícil de tratar era, sem dúvida, a dos "falsos" pacotes dinâmicos; ou o que é o mesmo, a comercialização de serviços turísticos que não são pacotes de viagem, pela Internet, efetuada por uma empresa que não é uma agência de viagens.

Com efeito, e apesar do regime geral de exclusividade, a LAVTP (art. ${ }^{\circ}$. $^{\circ}$ n. ${ }^{\circ}$ 3) abriu a porta a que um qualquer prestador de serviços turísticos, que não uma agência de viagens, pudesse comercializar, pela internet, serviços turísticos que não constituíssem uma viagem organizada $^{63,64}$. Havia, e continua a haver, muitos exemplos do que se disse, geralmente associados a companhias de aviação: Ryanair, Easyjet, Vueling, British Airways, Delta Airlines, para referir apenas algumas. E o modelo tem dado tão bons resultados que é hoje fácil assistir a este fenómeno em portais de internet de outras empresas, por exemplo, de transporte ferroviário ${ }^{65}$, ou mesmo nas grandes cadeias hoteleiras.

Na altura tomámos por exemplo o caso da companhia aérea Ryanair ${ }^{66}$, que oferecia no seu site serviços tão diversos como voos (o seu core business), reservas de hotéis e transfers. O problema era o de saber quem era o responsável por cada um dos serviços anunciados no portal ou, por outras palavras, com quem se estava a contratar os ditos serviços. Veja-se, a este propósito, a figura 1.

\footnotetext{
${ }^{63}$ Cfr. artigo $3^{\circ}$, n. ${ }^{3} 3$ da Lei das Agências de Viagem.

${ }^{64}$ Estamos em crer que esta abertura legal foi determinada, em larga medida, para acomodar o que muitas empresas turísticas vinham já fazendo.

${ }^{65}$ Cfr., por exemplo, o portal dos Comboios de Portugal (CP) em https://www.cp.pt/passageiros/pt.

${ }^{66}$ Cfr. Vidal, João A., La responsabilidad de las empresas turísticas frente a la problemática de los paquetes dinámicos: el caso de Portugal, Paquetes dinámicos de turismo: problemas y soluciones jurídicas desde una perspectiva internacional, Madrid: Ed. Dykinson, 2014
} 


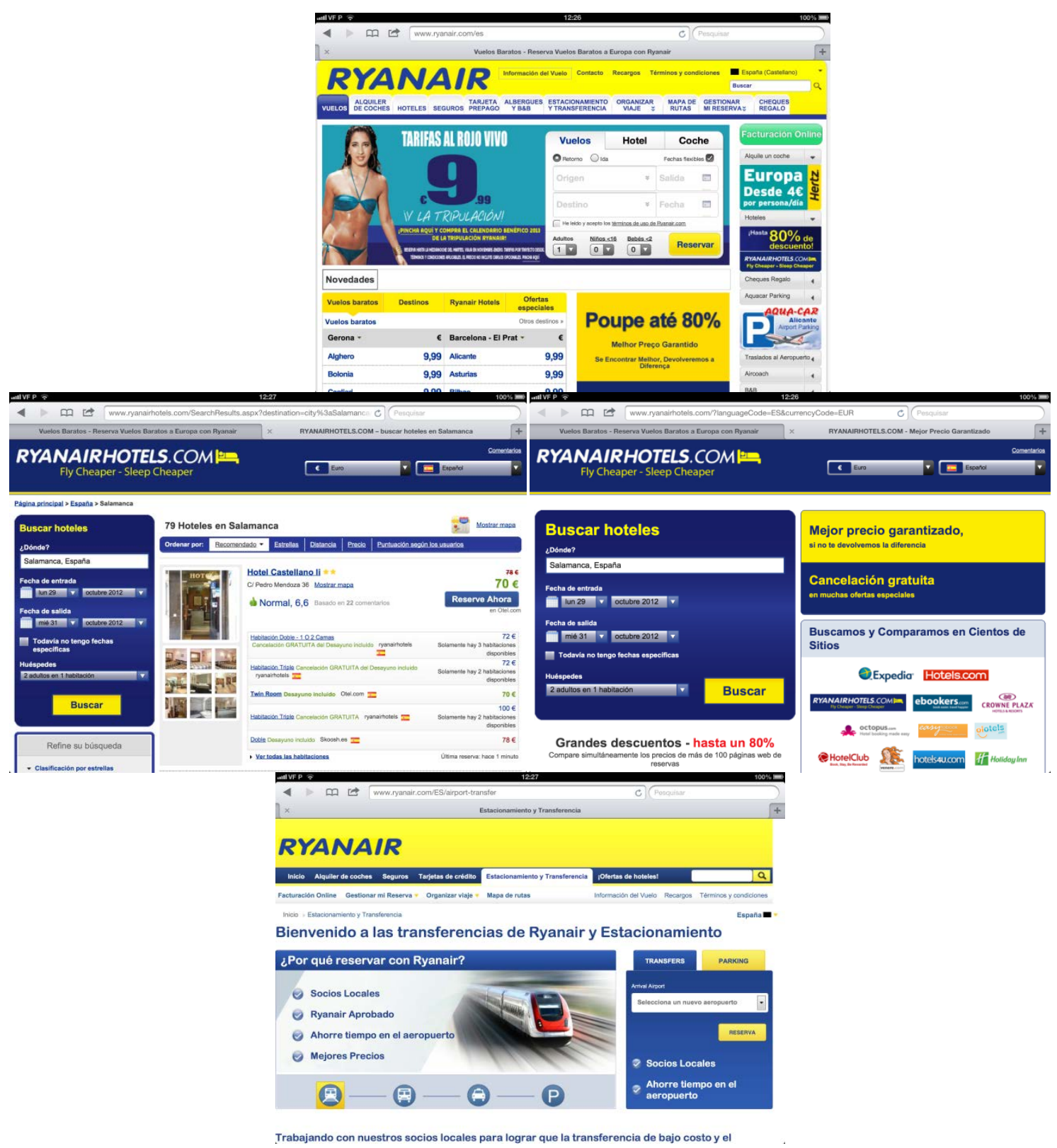

Figura 1

(Portal de Ryanair, versão em castelhano, no dia 27 de Outubro de 2012)

A figura evidenciava o facto do cliente, nos vários separadores do portal, ter sempre o nome/marca da Ryanair a encabeçar os ditos separadores. Na página dedicada aos hotéis foise ainda mais longe e criou-se uma marca e um logotipo: ryanairhotels.com, com o símbolo de uma cama por baixo do nome. Na altura entendíamos que para um turista médio ${ }^{67}$ era muito difícil compreender que não estava, na verdade, a negociar com a própria Ryanair, mas sim diretamente com o prestador do serviço em causa, o que naturalmente poderia gerar uma deficiente interpretação da realidade, com consequências nefastas para o turista.

\footnotetext{
${ }^{67}$ Bem sabemos quão difícil é a caracterização do homem médio no direito, em especial em matéria turística, com a sua transnacionalidade e a mistura cultural que lhe subjaz.
} 
Nestes casos, parecia-nos claro que não havia responsabilidade do proprietário da plataforma informática através da qual eram oferecidos os diferentes serviços. Na prática, o turista teria de processar diretamente o fornecedor de serviços, sendo que, na maioria das vezes, seria muito difícil, ou mesmo impossível, a reparação de eventuais danos. Este problema era ainda agravado pelo facto de, em virtude de criar a convicção, errada, de que estava a contratar com a companhia aérea, o turista descurar a recolha de elementos probatórios que lhe pudessem vir a ser úteis no momento de reclamar os danos sofridos.

\subsection{O pacote dinâmico na nova Diretiva 2015/2302.}

A nova Diretiva apresenta-se com o intuito de resolver os problemas identificados durante a vigência da anterior Diretiva e ainda introduzir algumas inovações no regime jurídico das viagens organizadas. No que respeita à responsabilidade, introduz-se o princípio da responsabilidade exclusiva do organizador ${ }^{68}\left(\right.$ art. $\left.^{\circ} 13^{\circ} \mathrm{n}^{\circ} 1\right)$, embora com direito de regresso contra os prestadores que tiverem dado azo a essa responsabilização(art. $\left.{ }^{\circ} 22^{\circ} n^{\circ} 1\right)$.

Por outro lado, assume-se expressamente a jurisprudência do Tribunal Europeu, alargando-se, como veremos adiante, o conceito "legal" de viagem organizada, bem como se alarga a responsabilidade à contratação em linha, o que vinha sendo reclamado por todos os atores no mercado do turismo.

Importa, agora, procurar saber se os falsos pacotes dinâmicos que havíamos identificado e que atiravam o turista para uma área muito nebulosa de responsabilização dos intervenientes, foram considerados na nova Diretiva e, se sim, qual o regime de responsabilidade que lhes está associado. Esta procura tem tanto mais interesse quanto é um facto público e notório que cada vez mais os turistas, ou viajantes, utilizam esta forma para contratar as suas viagens ${ }^{69}$. De resto, a regulação destes falsos pacotes dinâmicos é um desiderato do legislador comunitário desde há vários anos, empurrado pela constatação das realidades comerciais e pelos problemas que, aqui e ali, têm surgido, maxime, a insolvência de alguns operadores e companhias de aviação que puseram a nu algumas das fragilidades do edifício regulativo, deixando desprotegidos milhares de turistas.

Não é pacífica a perceção, entre os vários autores que se ocupam do tema, deste problema. Tal situação é ainda aumentada pelo facto de, apesar da harmonização levada a cabo pelas diretivas, estarmos a falar de diferentes ordenamentos jurídicos, com os seus princípios e regras próprias. Tanto assim é que, para alguns, a figura do pacote dinâmico corresponde aos novos serviços de viagem conexos $^{70}$. Não entendemos assim.

\footnotetext{
${ }^{65}$ Na anterior Diretiva (90/314/CEE) estabelecia-se uma responsabilização do operador (organizador) e da agência (retalhista) - Cfr. artigo $5^{\circ}$, n. ${ }^{\circ} 1$.

${ }^{66}$ Em 2009, segundo dados da União Europeia consultados em Overhauling EU rules on package travel. Frequently Asked Questions (MEMO/09/523), 56\% dos europeus organizavam eles mesmos as suas viagens. Acredita-se que hoje este número seja ainda maior e com tendência para aumentar.

${ }^{70}$ Cfr. Caletrio, Alfredo B., La contratación de viajes vinculados, Revista Doctrinal Aranzadi Civil-Mercantil num.6/2016 parte Estudio, Editorial Aranzadi, SA, Cizur Menor. 2016, que claramente afirma que " $L a$ regulación de los viajes vinculados que se propone en la Directiva no ha sido fruto de una elaboración pacífica. Desde hace ya algunos años se viene discutiendo entre los empresarios del sector turístico y entre los especialistas en la materia si a la contratación de los hasta ahora denominados "paquetes dinámicos de turismo" debía aplicársele o no el régimen jurídico de los viajes combinados (por ser ésta la normativa que
} 
Declara a própria Diretiva, no seu Considerando $9^{\circ}$, que, por motivos de transparência, deverá ser feita uma distinção entre as viagens organizadas e os serviços de viagem conexos mediante os quais operadores em linha ou tradicionais facilitam a aquisição de serviços de viagem pelos viajantes, implicando a celebração de contratos com diferentes prestadores de serviços de viagem, inclusive através de processos interligados de reserva, que não apresentam as características das viagens organizadas e aos quais não seria adequado aplicar todas as obrigações aplicáveis às viagens organizadas.

A nova diretiva aporta, pois, uma real novidade ao mundo do turismo, que em Portugal se entendeu por bem chamar de "serviços de viagem conexos"71. E a principal característica deste novo tipo de serviço de viagem radica no aparecimento de um facilitador, que pode ser uma agência de viagens ou não ${ }^{72}$, agora denominado uniformemente "operador" e ainda no facto dos contratos serem celebrados com diferentes prestadores de serviços e pagos separadamente.

Como a própria diretiva esclarece, no seu considerando $13^{\circ}$, estas regras seriam aplicáveis, nomeadamente, quando, a par da confirmação da reserva de um primeiro serviço de viagem, como uma viagem de avião ou de comboio, o viajante é convidado a reservar outros serviços de viagem disponíveis no destino de viagem escolhido, por exemplo, o alojamento num hotel, com uma hiperligação para o sítio web de reservas de outro prestador de serviços ou intermediário. No mesmo considerando mais se esclarece que, se bem que estes serviços não devam constituir viagens organizadas na aceção da presente diretiva, no âmbito dos quais o operador seja responsável pela execução correta dos serviços de viagem, tais serviços de viagem conexos constituem um modelo de negócio alternativo que, muitas vezes, faz forte concorrência às viagens organizadas.

Do texto da Diretiva resulta óbvio que o legislador comunitário tinha em mente, de forma muito precisa, os sítios da internet em que, a par da venda do serviço fornecido pelo titular da plataforma, outros serviços turísticos são vendidos, em conexão com o primeiro ${ }^{73,74}$. O legislador comunitário recebeu, portanto, as diversas críticas que vinham sendo feitas a este modus operandi, comercialmente eficaz, mas penalizador para os consumidores/turistas.

Fê-lo, eventualmente, num momento tardio, em que já muitos operadores desse tipo de plataforma haviam voluntariamente alterado a forma como se apresentavam no mercado. A

ofrece una mayor protección al consumidor que adquiere un conjunto de servicios jurídicos). En el fondo, lo que se ha estado discutiendo es si a los viajeros que contrataban servicios turísticos de esta manera se les debían reconocer o no los derechos que... reconocía a los consumidores que contrataban viajes combinados, especialmente los que derivaban de supuestos de responsabilidad de los empresarios por una deficiente ejecución del viaje combinado y de la insolvencia del organizador o minorista. Como veremos inmediatamente después, con la aprobación de esta Directiva se pone fin a la discusión.”

${ }^{71}$ Apenas como exemplo, refira-se que os ingleses chamaram a esta realidade "linked travel arrangement", os franceses "prestation de voyage liée”, e os espanhóis "servicios de viaje vinculados”, o que bem demonstra a disparidade de entendimentos que podem surgir apenas em virtude das diferentes palavras utilizadas.

${ }^{72}$ Facto a que o legislador terá que dar atenção, atento o princípio da exclusividade existente em Portugal, que apenas permite às agências de viagens vender serviços turísticos.

${ }^{73}$ Em linha com o problema já por nós identificado em 2012, in Vidal, João A., La responsabilidad de las empresas turísticas frente a la problemática de los paquetes dinámicos: el caso de Portugal, Paquetes dinámicos de turismo: problemas y soluciones jurídicas desde una perspectiva internacional, Madrid: Ed. Dykinson, 2014.

${ }^{74}$ Os exemplos mais flagrantes destes sítios de internet são os das denominadas companhias aéreas low cost a operar no mercado europeu. 
este propósito, importa voltar ao grafismo e apresentar (figura 3), para maior facilidade de apreensão e comparação de práticas, o sítio da Ryanair, agora em 2015:

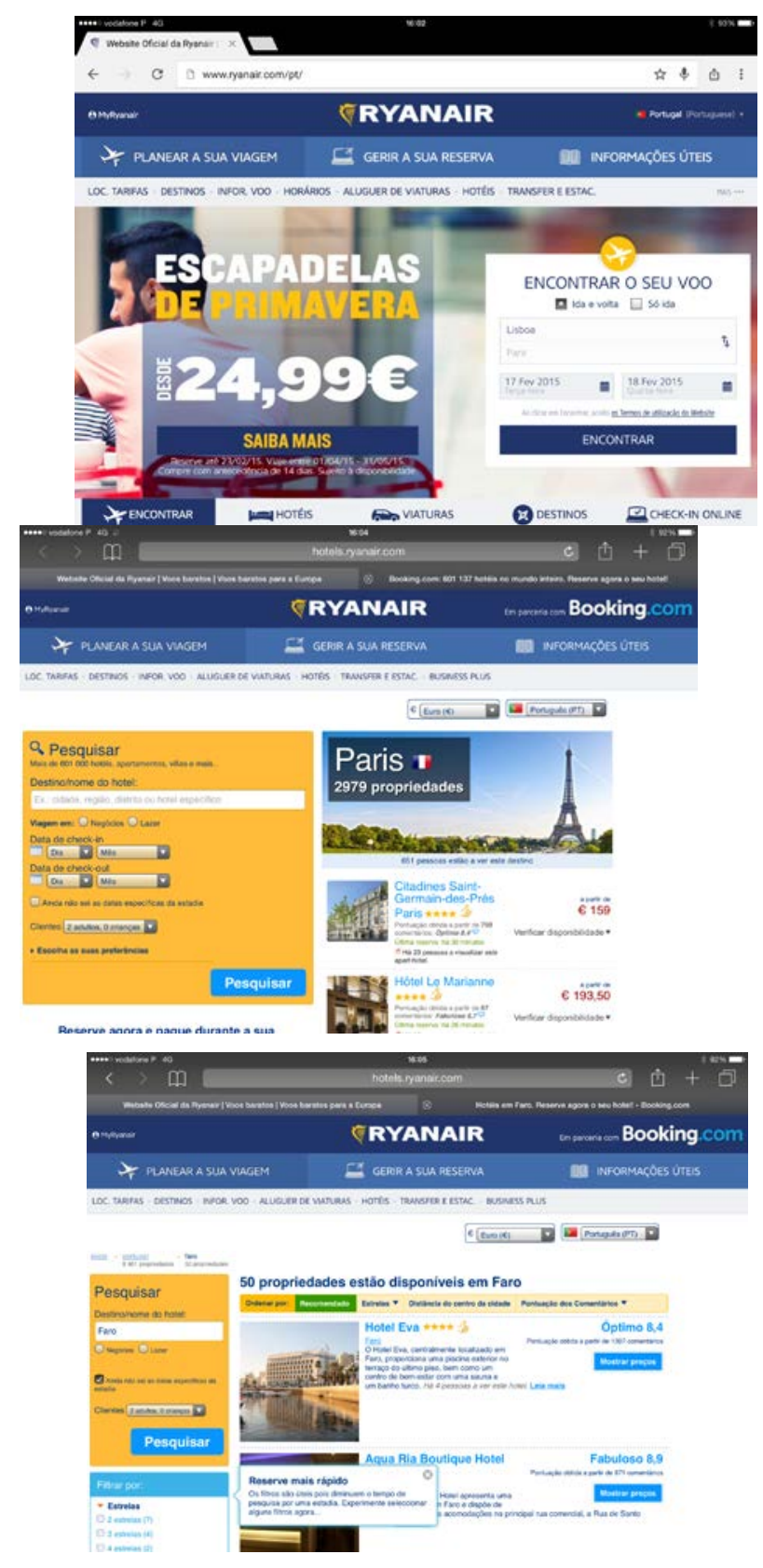

Figura 3

(Portal da Ryanair, versão em português, em Fevereiro de 2015)

Como se vê na figura 3, a Ryanair, já no início de 2015 e provavelmente sensível às críticas supra referidas, havia alterado radicalmente o layout da sua página, deixando agora claro que os restantes serviços comercializados - no exemplo da figura, o alojamento - eram prestados por um parceiro, no caso a booking.com. Mas nem todas as companhias aéreas low 
cost seguiam este exemplo ${ }^{75}$. Muitas continuavam a oferecer diversos serviços nos seus portais sem que a identificação do real prestador fosse óbvia ou evidente. Veja-se infra (figura 4), a título de exemplo, o sítio de internet de outra companhia aérea low cost, também em 2015.

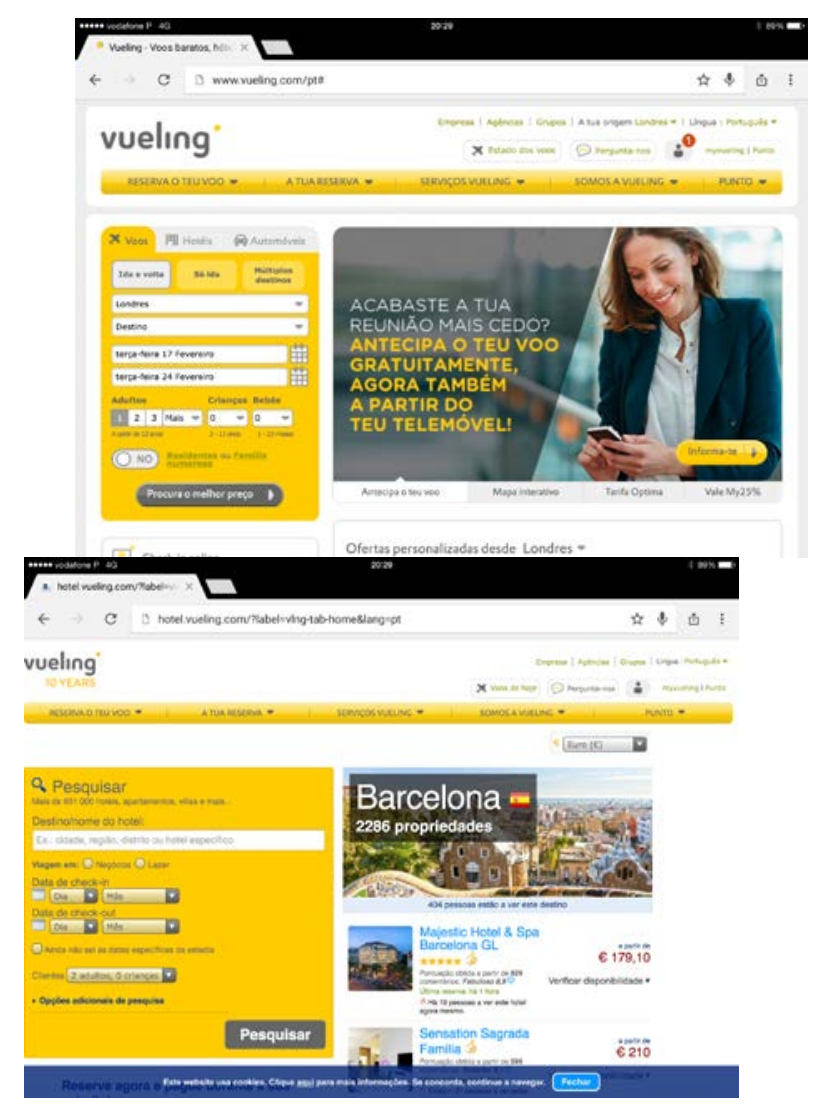

Figura 4

(Portal da Vueling, versão em português, em Fevereiro de 2015)

Como facilmente se constata, no portal da Vueling continuava a existir a possibilidade de reservar um hotel diretamente na página da companhia aérea mas, uma vez clicado o respetivo separador, nenhuma informação era apresentada sobre o real prestador do serviço ${ }^{76}$.

Serão, então, os agora denominados «serviços de viagem conexos» os anteriores falsos pacotes dinâmicos? Parece que sim. Mas a questão não é tão simples quanto, à primeira vista, possa parecer. É que o legislador comunitário, seguramente na ânsia de alcançar uma regulação o mais abrangente possível, introduziu alguns fatores que baralham o intérprete.

Os «serviços de viagem conexos», tal como são definidos na nova diretiva, são pelo menos dois tipos diferentes de serviços de viagem adquiridos para efeitos da mesma viagem ou das mesmas férias que não constituam uma viagem organizada e que resultem na

\footnotetext{
${ }^{75}$ Para nós, claramente um bom exemplo.

${ }^{76}$ Que no caso, e após muita e difícil pesquisa, era igualmente a Booking.com.
} 
celebração de contratos distintos com diferentes prestadores de serviços de viagem, se um operador $^{77}$ facilitar $^{78}$ :

a) Por ocasião de uma mesma visita ou contacto com o respetivo ponto de venda, a escolha separada e o pagamento separado de cada serviço de viagem pelos viajantes; ou

b) De forma direcionada, a aquisição de pelo menos um serviço de viagem adicional a outro operador, caso o contrato com esse outro operador seja celebrado o mais tardar 24 horas depois da confirmação da reserva do primeiro serviço de viagem (art. ${ }^{\circ} 3 .^{\circ}$ n. ${ }^{\circ}$ ).

Os serviços de viagem conexos exigem, pois, a intervenção de um operador ${ }^{79}$ que facilite a contratação entre o viajante e os prestadores finais do serviço de viagem contratado. A Diretiva permite ainda que o operador, para além de facilitar a contratação, possa ele mesmo prestar algum dos serviços turísticos adquiridos ${ }^{80}$.

O conceito de facilitador presente na Diretiva é, também ele, importante para a correta qualificação de um determinado contrato de serviço turístico. Neste caso, à atividade de facilitação deverá corresponder uma relação comercial remunerada entre o facilitador e o prestador final do serviço em causa ${ }^{81}$, assumindo o facilitador, em especial nos casos em que ele próprio seja também prestador de um dos serviços, uma importante função de garantia, que lhe impõe ser especialmente diligente na forma e conteúdo da informação que presta ao viajante, para evitar que este incorra em erros no momento de celebrar o contrato. Estes deveres de informação são ainda mais severos, como bem alerta Alfredo Caletrio, nos casos em que a contratação se realiza eletronicamente ${ }^{82}$.

A Diretiva deixa igualmente claro quais os casos em que não pode considerar-se um determinado serviço como sendo serviço de viagem conexo ${ }^{83}$. Assim, não se consideram serviços de viagem conexos aqueles que não ultrapassem as 24 horas, salvo se incluírem uma pernoita, aqueles que se prestam de forma ocasional, sem o objetivo do lucro e apenas a um grupo reduzido de viajantes, e ainda aqueles que são prestados com base num acordo geral e prévio para a organização de viagens de negócios entre um operador e outra pessoa singular ou coletiva que atue para fins que se insiram no âmbito da sua atividade comercial,

\footnotetext{
77 «Operador» é qualquer pessoa singular ou coletiva, pública ou privada, que, nos contratos abrangidos pela presente diretiva, atue, inclusive através de outra pessoa que atue em seu nome ou por sua conta, para fins relativos à sua atividade comercial, empresarial, artesanal ou profissional, quer atue como organizador, retalhista, operador que facilita serviços de viagem conexos ou como prestador de um serviço de viagem.

${ }^{78}$ Na prática, e na maioria das situações, os facilitadores serão as companhias aéreas, as agências de viagens e, embora com menos relevância, os hotéis e empresas de aluguer de veículos.

${ }^{79}$ A opção pela palavra “operador” para nomear o conceito existente na Diretiva é altamente criticável, porquanto contende com toda a história da regulamentação das viagens em Portugal, na qual o operador estava perfeitamente identificado.

${ }^{80}$ É o caso clássico das companhias aéreas, que prestam elas próprias um dos serviços turísticos existentes: o transporte.

${ }^{81}$ O critério de remuneração poderá variar, mas os mais usados no turismo são o número de cliques e uma percentagem sobre as vendas.

${ }^{82}$ Nestes casos, o facilitador tem três funções autónomas e juridicamente relevantes: a de facilitador, a de prestador de serviços de viagem, e a de prestador de serviços de informação.

${ }^{83}$ Cfr. artigo $2^{\circ}$ da Diretiva.
} 
empresarial, artesanal ou profissional. As razões destas exclusões radicam na reduzida necessidade de proteção dos primeiros ${ }^{84}$, na falta do objetivo do lucro, nos segundos, e na também mais reduzida necessidade de proteção quando o viajante beneficia das condições negociadas entre o operador e a empresa de que é parte ${ }^{85}$.

Dito isto, importa agora revisitar o conceito de viagem organizada na Diretiva 2015/2302 art. $^{\circ} 3 .^{\circ} n^{\circ}$ 2) e apenas na parte que nos interessa para estabelecer a comparação com os serviços de viagem conexos. Assim, temos que a viagem organizada é, também, a combinação de pelo menos dois tipos diferentes de serviços de viagem para efeitos da mesma viagem ou férias se:

a)...

b) Independentemente de serem celebrados contratos distintos com diferentes prestadores de serviços de viagem, esses serviços forem:

v) adquiridos a diferentes operadores mediante processos interligados de reserva em linha, pelos quais o nome do viajante, os dados relativos ao pagamento e o endereço eletrónico são transmitidos pelo operador com quem o primeiro contrato é celebrado a outro operador ou operadores, sendo celebrado um contrato com o último operador o mais tardar 24 horas após a confirmação da reserva do primeiro serviço de viagem.

O segmento do artigo $3^{\circ}$ da Diretiva que acabámos de transcrever introduz uma importante dúvida no intérprete. É que, afinal, também a viagem organizada pode implicar a celebração de diferentes contratos de prestação de serviços, com diferentes prestadores de serviços e, portanto, pagos de forma separada, desde que os vários serviços sejam adquiridos a diferentes operadores mediante processos interligados de reserva em linha, pelos quais o nome do viajante, os dados relativos ao pagamento e o endereço eletrónico são transmitidos pelo operador com quem o primeiro contrato é celebrado a outro operador ou operadores, sendo celebrado um contrato com o último operador o mais tardar 24 horas após a confirmação da reserva do primeiro serviço de viagem (sublinhado nosso).

Da comparação dos dois conceitos, viagem organizada e serviços de viagem conexos, resulta, pois, que aquilo que os distinguirá, no caso da celebração de diferentes contratos com diferentes prestadores de serviços, será, apenas, o facto de, nos primeiros, o operador com quem primeiro se contrata transmitir aos outros operadores o nome do viajante, os dados relativos ao pagamento e o seu endereço de correio eletrónico( sublinhado nosso).

Nos exemplos que temos vindo a utilizar, se a companhia aérea transmitir ao hotel ou à empresa de aluguer de automóveis o nome do viajante, os dados do pagamento e o seu endereço de correio eletrónico, então deverá considerar-se tal viagem, como uma viagem organizada, com todas as consequências em matéria de responsabilidade daí advenientes. Se o não fez, então ficaremos pela proteção dos serviços de viagem conexos.

Conclui-se, pois, que, muito embora o legislador europeu tenha querido, nos serviços de viagem conexos, restringir a responsabilidade pelo incumprimento ou pelo cumprimento

\footnotetext{
${ }^{84}$ Os danos são menores em viagens de curta duração.

${ }^{85}$ Se bem compreendemos as duas primeiras exclusões, temos mais dificuldade em aceitar a terceira, porquanto o viajante ficará, neste caso e na eventualidade de uma insolvência, por exemplo, numa situação em que o prévio contrato existente pouco ou nada o ajudará.
} 
defeituoso ao prestador de serviços incumpridor, abriu a porta à responsabilização de outros intervenientes no processo através do amplo conceito de viagem organizada ${ }^{86}$, que a seguir enunciaremos melhor.

\section{AS VIAGENS ORGANIZADAS E REGIME DE RESPONSABILIDADE NA NOVA DIRETIVA 2015/2302.}

Segundo o art. $^{\circ} 3^{\circ} n^{\circ} 2$ da nova Diretiva, “viagem organizada”, será a combinação de pelo menos dois tipos diferentes de serviços de viagem para efeitos da mesma viagem ou férias se:

a) Esses serviços forem combinados por um único operador, incluindo a pedido ou segundo a escolha do viajante, antes de ser celebrado um contrato único relativo à globalidade dos serviços; ou

b) Independentemente de serem celebrados contratos distintos com diferentes prestadores de serviços de viagem, esses serviços forem: i) adquiridos num ponto de venda único e tiverem sido escolhidos antes de o viajante aceitar o pagamento, ii) propostos para venda, vendidos ou faturados por um preço global, iii) publicitados ou vendidos sob a denominação «viagem organizada» ou qualquer outra expressão análoga, iv) combinados após a celebração de um contrato através do qual o operador dá ao viajante a possibilidade de escolher entre uma seleção de diferentes tipos de serviços de viagem, ou v) adquiridos a diferentes operadores mediante processos interligados de reserva em linha, pelos quais o nome do viajante, os dados relativos ao pagamento e o endereço eletrónico são transmitidos pelo operador com quem o primeiro contrato é celebrado a outro operador ou operadores, sendo celebrado um contrato com o último operador o mais tardar 24 horas após a confirmação da reserva do primeiro serviço de viagem.

Por sua vez, o art. $^{\circ} 3^{\circ}$ n. ${ }^{\circ} 1$ da Diretiva explicita como "serviços de viagem»: a) $\mathrm{O}$ transporte de passageiros; b) $\mathrm{O}$ alojamento que não seja parte integrante do transporte de passageiros e não tenha fins residenciais; c) $\mathrm{O}$ aluguer de carros ou de outros veículos a motor; d) Qualquer outro serviço turístico que não seja parte integrante de um serviço de viagem, na aceção das alíneas a), b) ou c); neste último caso desde que:

a) Representem uma proporção significativa do valor da combinação e não forem publicitados como constituindo uma característica essencial da combinação nem representarem de outro modo uma tal característica; ou

b) Não forem escolhidos e adquiridos apenas depois de ter sido iniciada a execução de um serviço de viagem a que se refere o ponto 1 , alíneas a), b) ou c)- art. $^{\circ} 3^{\circ} n^{\circ} 2$ parte final $a$ contrario.

\footnotetext{
${ }^{86}$ A distinção entre as duas figuras é tão ligeira que vários especialistas e comentadores não tiveram dúvidas em afirmar que "under the new regime airlines and websites, currently unbonded, will have to adhere to the same regulations. Consumers who click through on an airline website to a hotel or car hire company are effectively buying a package and entitled to the same protection and compensation levels, including repatriation, compensation for the failure of a third party firm and a cooling off period. Domain owners will also be responsible for three days' cover in the eventuality of a major disruption such as the ash crisis"
} 
A nova Diretiva veio, sem margem para dúvidas, alargar o conceito de viagem organizada a realidades que, até aqui, ou já integravam o conceito apenas pelo labor jurisprudencial, ou não o integravam de todo.

A «viagem organizada» é agora a combinação de pelo menos dois tipos diferentes de serviços de viagem (de entre o transporte de passageiros, alojamento, aluguer de veículos e qualquer outro serviço turístico que não seja parte integrante de um serviço de viagem), para efeitos da mesma viagem ou férias, se esses serviços forem combinados por um único operador, incluindo a pedido ou segundo a escolha do viajante, antes de ser celebrado um contrato único relativo à globalidade dos serviços, ainda que adquiridos a diferentes operadores mediante processos interligados de reserva em linha.

Do texto dúvidas não subsistem de que o regime da viagem organizada se estende agora à viagem taylor made e que o processo contratual, ou de reserva, seja efetuado em linha, com recurso à internet. Neste caso, porém, e com extrema relevância para a interpretação desta norma, aparece a exigência de que os dados relativos ao pagamento e endereço eletrónico (do viajante) sejam transmitidos pelo operador com quem o primeiro contrato é celebrado a outro operador ou operadores, sendo celebrado um contrato com o último operador o mais tardar 24 horas após a confirmação da reserva do primeiro serviço de viagem.

O novo conceito não é fácil e não está, seguramente, isento de críticas. O aspeto mais controverso do novo conceito reside, para nós, na exigência da transmissão dos dados relativos ao pagamento e endereço eletrónico do viajante por um prestador a outro prestador. É que se, em condições de raciocínio teórico e abstrato, se consegue alcançar, com relativa clareza, o espírito da norma, já não nos parece tão claro que, na operação prática que subjaz ao conceito, essa facilidade subsista.

Acresce a dificuldade, que abordaremos infra, de que este pode ser o critério último e único, para distinguir uma viagem organizada da prestação de um serviço de viagem conexo. Terá o viajante sempre facilidade em saber, para poder catalogar a viagem que comprou, se os dados relativos ao pagamento e ao seu endereço eletrónico foram transmitidos por um prestador a outro? Temos sérias dúvidas.

Ora bem, toda esta formulação a propósito dos pacotes dinâmicos, facilitação de serviços conexos e viagens organizadas é mais um contributo para a resposta afirmativa ao problema de investigação colocado, ou seja, o regime jurídico das viagens organizadas e serviços conexos da nova Diretiva é um constituinte à integração económica em rede das organizações públicas e privadas que organizam ou facilitam a venda de viagens e serviços turísticos.

A aquisição a diferentes operadores mediante processos interligados de reserva em linha de diversos serviços turísticos nas viagens organizadas, o conceito de facilitador (v.g. pela Internet) nos serviços conexos na celebração de contactos distintos com diferentes prestadores de serviços por ocasião conexa de uma visita ou contacto com o respetivo ponto de venda e o próprio conceito de operador em turismo, que aglutina dimensões tão distintas, como a sua natureza pública ou privada ou de organizador ou retalhista, indiciam instrumentos regulatórios importantes e fundamentais para aquela integração. 
Esta integração também é apoiada na responsabilidade exclusiva do organizador. Na verdade, o artigo $13^{\circ} \mathrm{n}^{\circ} 1$ da Diretiva estabelece, em linha com o disposto na anterior Diretiva, que os Estados-Membros asseguram que o organizador seja responsável pela execução dos serviços de viagem incluídos no contrato de viagem organizada, independentemente de esses serviços serem executados pelo próprio organizador ou por outros prestadores de serviços de viagem.

No entanto, os Estados-Membros poderão manter ou introduzir disposições no direito nacional segundo as quais o retalhista também seja responsável pela execução da viagem organizada. É a única excepção que verificamos ao regime do nível de harmonização máxima do art. $^{\circ} 4^{\circ}$ da Diretiva, concedendo-se tutela a regimes nacionais (como o português- art. ${ }^{\circ} 29^{\circ}$ $\mathrm{n}^{\circ} 3$ da LAVTP) que ainda responsabilizam integralmente o retalhista.

Este regime de solidariedade, ainda que tutelando o princípio da proximidade e da confiança da relação do retalhista-consumidor, parece-nos algo iníquo ao exigir uma responsabilidade integral e solidária pelo dano (quando a margem de lucro do retalhista pode ser reduzida), prejuízo que pode apenas ser mitigado pela tutela geral de um direito de regresso contra o causador do dano regulável, seja pelo art. ${ }^{\circ} 22^{\circ}$ da Diretiva, seja pelas leis nacionais.

Realmente inovadora é a menção expressa aos problemas gerados pela insolvência do organizador, que se autonomiza nos artigos $17^{\circ}$ e $18^{\circ}$ da Diretiva, e estabelece que os EstadosMembros asseguram que os organizadores estabelecidos no seu território garantem o reembolso de todos os pagamentos efetuados pelos viajantes ou por conta destes na medida em que os serviços em causa não sejam executados em consequência da declaração da insolvência do organizador. Mais se acrescenta, de forma expressa, que se no contrato de viagem organizada estiver incluído o transporte de passageiros, os organizadores devem igualmente garantir o repatriamento dos viajantes.

Não é de estranhar a menção expressa aos casos de insolvência, porquanto no decurso da formação da Diretiva vários casos de insolvência ocorreram na Europa que deixaram muitos turistas desprotegidos ${ }^{87}$.

E o que dizer da responsabilidade decorrente da prestação de serviços de viagem conexos? Regem aqui os artigos $19^{\circ}$ e $21^{\circ}$ da Diretiva, naquilo que é uma verdadeira novidade regulativa nesta matéria. Distingue-se agora entre a responsabilidade que deriva do incumprimento de alguma das prestações que compõem os serviços de viagem conexos, da que tem origem na insolvência do operador que facilitou a sua contratação ${ }^{88}$, e ainda da responsabilidade proveniente de um erro na reserva ${ }^{89}$.

No que toca à responsabilidade por incumprimento de prestações que compõem os serviços de viagem conexos, a Diretiva é clara e estabelece que o único responsável será o prestador que falhou o cumprimento. No entanto, e este é um aspeto muito importante do novo regime, a exclusão de responsabilidade do facilitador só opera ${ }^{90}$ se este tiver cumprido

\footnotetext{
${ }^{87}$ A lista completa seria extensa, mas destacamos, a título de exemplo, as insolvências da espanhola Marsans, das portuguesas Netviagens.com e Mundi Travel, da francesa Framvoyages, das inglesas Low Cost Travel Group e XL Leisure Group.

${ }^{88}$ Ambas previstas no artigo $19^{\circ}$ da Diretiva.

${ }^{89}$ Prevista no artigo $21^{\circ}$ da Diretiva.

${ }^{90}$ Cfr. artigo $19^{\circ}$, n. ${ }^{\circ}$, da Diretiva.
} 
as obrigações de informação constantes do n. ${ }^{\circ} 2$ do artigo $19^{\circ}$, que lhe impõem que comunique, de forma clara, compreensível e bem visível ao viajante, que este não beneficiará dos direitos que se aplicam exclusivamente a viagens organizadas ao abrigo da diretiva, que cada prestador de serviços será o único responsável pela correta execução contratual do seu serviço, e que beneficiará da proteção em caso de insolvência, prevista no n. ${ }^{\circ} 1$ do mesmo artigo $^{91}$.

Uma outra fonte de responsabilidade decorrente da contratação de serviços de viagem conexos é a insolvência do facilitador. Dispõe o n. ${ }^{\circ} 1$ do artigo $19^{\circ}$ da Diretiva que os "Estados-Membros asseguram que os operadores que facilitam serviços de viagem conexos garantam o reembolso de todos os pagamentos que recebam dos viajantes, na medida em que o serviço de viagem que faz parte de um serviço de viagem conexo não seja executado em consequência da declaração da sua insolvência. Se tais operadores forem a parte responsável pelo transporte dos passageiros, a garantia abrange também o repatriamento do viajante. $O$ artigo $17^{\circ} \mathrm{n}^{\circ} 1$, segundo parágrafo, os $n .^{\circ} \mathrm{s} 2$ a 5 , e o artigo $18 .^{\circ}$ são aplicáveis com as devidas adaptações."

A redação deste artigo em português é clara ${ }^{92}$ e não oferece dúvidas: os viajantes ficarão protegidos na eventualidade da insolvência do facilitador dos serviços de viagem conexos determinar a impossibilidade de os receber. A forma como, em concreto, se efetivará esta proteção já não é tão clara. A Diretiva manda que os Estados-membros assegurem que os facilitadores "garantam" o reembolso dos pagamentos que receberam dos viajantes se o serviço de viagem não puder ser prestado em virtude da sua insolvência. Surge aqui a primeira dúvida: nos serviços de viagem conexos: a regra é a de que os serviços são individualmente contratados e pagos em separado. Será então uma companhia aérea declarada insolvente responsável pela devolução do dinheiro pago pelo viajante ao hotel, onde o viajante não chegou por causa da insolvência daquela? Parece que sim, em função da remissão feita no artigo $19^{\circ}$ para o n. ${ }^{\circ}$, do artigo $17^{\circ}$, todos da Diretiva.

A segunda questão será a forma como operará esta garantia ${ }^{93}$. Neste domínio, cremos que o ordenamento jurídico português está já apetrechado para lidar com o novo problema, precisamente, pela existência da previsão de um Fundo Solidário de Garantia ${ }^{94}$ que responde solidariamente pelo pagamento dos créditos de consumidores decorrentes do incumprimento de serviços contratados às agências de viagens e turismo (art. ${ }^{\circ} 31 .^{\circ} \mathrm{n}^{\circ} 1$ da LAVTP). O problema aqui é que o Fundo Solidário, tal como existe atualmente, tem um limite anual de pagamentos de $€ 1.000 .000,00$, o que pode ser claramente insuficiente para fazer face a um processo de insolvência de um "grande" facilitador de serviços de viagem conexos.

\footnotetext{
${ }^{91}$ Quer isto dizer que, ao abrigo da nova diretiva, e continuando nos exemplos supra referidos dos portais das companhias aéreas, o viajante que comprar um bilhete de avião e aluguer um automóvel, se houver incumprimento por parte da empresa de aluguer de automóveis, apenas contra esta poderá exercer os seus direitos. De igual modo, se o incumprimento for do viajante naquela relação, a empresa que alugou o automóvel apenas poderá demandar o viajante e nunca a companhia aérea que facilitou a aquisição daquele serviço de viagem conexo. Tudo no pressuposto, claro, que a companhia aérea cumpriu o dever de informação constante da Diretiva.

${ }^{92}$ A redação em espanhol, por exemplo, oferece dúvidas, no entender de Batuecas, A., obra citada.

${ }^{93}$ Em Espanha, foi já aventado que esta garantia deverá ser prestada através de um seguro ou de uma caução, conforme existia no ordenamento jurídico português até 2011. Cfr. Calatrio, A., obra citada.

${ }^{94}$ É caso para dizer que Portugal tem, nestas matérias, andado à frente do seu tempo.
} 
Não nos parece que sobre outro caminho que o de aumentar a capacidade de resposta do Fundo Solidário ${ }^{95}$ nos casos de insolvência, mas igualmente não nos parece que esse aumento de capacidade do Fundo possa ser feito com as mesmas regras que atualmente existem para as contribuições para o mesmo. Estar-se-ia, nesta hipótese, a agravar ainda mais a situação de muitas pequenas e médias empresas, chamadas a contribuir para a garantia de um risco para o qual elas próprias pouco ou nada concorrem. E seria ainda um perigoso convite, como bem tem alertado Carlos Torres ${ }^{96}$, para que operadores estrangeiros estabeleçam a base da sua operação em Portugal, por forma a aliviar o esforço de cumprimento dos requisitos europeus de responsabilidade, o que, de todo, não pode, nem deve, permitir-se.

\section{A ORGANIZAÇÃO EM REDE TURÍSTICA DA UNIÃO.}

Apresenta-se, agora, um resumo conclusivo final sobre o problema de investigação colocado. Os indicadores atrás referidos sobre o nível de harmonização máximo exigido pela Diretiva, a uniformização do conceito de "operador”, qual operador em rede, permitindo, com base em processos em linha e o uso de tecnologias de informação e comunicação, o acesso à contratualização de uma série de tipologias de contratos (pacotes dinâmicos, viagens organizadas, serviços conexos) a diversos títulos, apontam para um grau de integração económica muito exigente a que o setor do turismo em geral e as viagens turisticas em particular se deverão adaptar.

Isto significa duas coisas fundamentais: que os operadores em turismo deverão dispor de um conjunto de recursos relacionados com a criação, controlo e comunicação de informação eletrónica e informática, que alguns Autores, como $\mathrm{Nyr}^{97}$, denominam “ciberpoder”, como também que o valor da informação, sua angariação, produção e difusão numa rede de confiança serão vitais para a sua sobrevivência e competitividade.

O conjunto das informações pré-contratuais exigidos ao organizador e retalhista (art. ${ }^{\circ}$ $5^{\circ}$ ), nomeadamente, quanto às principais características dos serviços de viagem (alínea a)), o tipo de custos adicionais envolvidos para além do preço quando este não possa ser razoavelmente calculado antes da celebração do contrato (alínea c)), dando-se primazia (art. ${ }^{\circ}$ $5^{\circ} \mathrm{n}^{\circ} 1$ ) a informações padronizadas em fichas informativas (Anexo I- Partes A,B e C) indiciam as exigências comunitárias do valor da informação integrada, sua organização e comunicação nos contratos dos operadores e/ou facilitadores em viagens e turismo. Estas têm carácter vinculativo $\left(\right.$ art. $\left.^{\circ} 6^{\circ}\right)$.

Reforça-se que estas informações pré-contratuais são transportadas, com aceitação do viajante, automaticamente, para um contrato de venda de viagem organizado (art. ${ }^{\circ} .^{\circ} \mathrm{n}^{\mathrm{o}} 2$ alínea a)) padronizado, com indicações de assumpção de responsabilidade e de assistência

\footnotetext{
${ }^{95}$ A não ser que se crie um amplo consenso em Portugal de que a experiencia do Fundo Solidário fracassou, devendo ser substituído por uma outra figura de garantia, o que não estamos em crer venha a acontecer.

${ }^{96}$ Cfr. Torres, Carlos, in Publituris, 18 de Fevereiro de 2016

${ }^{97}$ Ob. cit, pg.145.
} 
(alínea b)), incluindo formas de comunicação com o viajante por falta de conformidade dos serviços prestados (alínea e)) ou de resolução alternativa de litígios (alínea g)).

Já referimos o cuidado com o que o legislador da Diretiva tratou da questão da protecção do viajante em caso de insolvência do organizador nas viagens organizadas (art. ${ }^{\circ}$ $17^{\circ}$ ) e do prestador de serviços turísticos nos serviços conexos (art. ${ }^{\circ} 19^{\circ}$ ). Na continuidade do valor da informação já referido, o legislador impõe ao operador que facilita os serviços de viagens conexos uma ficha normativa normalizada com a informação sobre essa protecção (Anexo II) no caso de ser ou não um transportador que vende bilhetes de ida e volta (Partes A e B), neste ultimo caso, especificando fichas informativas para contratos que sejam celebrados simultaneamente na presença física do operador (Parte C) ou que não o sejam (Parte D-para transportadora e Parte E- para operadora não transportadora).

A padronização contratual pretendida é, assim, uma pedra de toque fundamental na venda, incluindo on-line, de viagens e serviços turísticos. Resta acrescentar, na senda de Granovetter $^{98}$, que uma organização, incluindo de Estados-nação em rede, necessita, para além de troca e partilha de informações de relações frequentes, duradouras, interpessoais que favoreçam a coesão social e emocional de pertença a um território comum.

Veja-se, a este propósito, o regime do exemplar art. ${ }^{0} 18^{\circ}$, n. $^{\circ}$ 2, 3 e 4 da Diretiva que passamos a transcrever:

"2. Os Estados-Membros designam pontos de contacto centrais para facilitar a cooperação administrativa e a supervisão dos organizadores que exercem a sua atividade em vários Estados-Membros. Os Estados-Membros comunicam os contactos desses pontos de contacto a todos os outros Estados-Membros e à Comissão."

"3. Os pontos de contacto centrais trocam entre si todas as informações necessárias sobre os requisitos nacionais de proteção em caso de insolvência e a identidade da entidade ou entidades que garantem a proteção em caso de insolvência a organizadores específicos estabelecidos no seu território. Os referidos pontos de contacto facultam o acesso recíproco aos inventários disponíveis dos organizadores que cumprem as respetivas obrigações de proteção em caso de insolvência. Esses inventários são acessíveis ao público, inclusive em linha”.

"4. Se tiverem dúvidas quanto à proteção em caso de insolvência de um organizador, os Estados-Membros solicitam esclarecimentos ao Estado-Membro onde está estabelecido o organizador. Os Estados-Membros respondem aos pedidos dos outros Estados-Membros o mais rapidamente possível, tendo em conta a urgência e a complexidade da questão. Em todo o caso, deve ser dada uma primeira resposta, o mais tardar, 15 dias úteis a contar da data de receção do pedido".

\footnotetext{
${ }^{98}$ Granovetter, M., “Economic Action and Social Structure: The problem of Embeddedness”, American Journal of Sociology, $\mathrm{n}^{\circ}$ 3, pp.481-510, 1985.
} 
Esta dimensão da organização-rede dos Estados-Membros (pontos de contacto centrais (os nós da rede) com a partilha de informações, dever de assistência recíproco) também é reforçada no art. $^{\circ} 26^{\circ}$ da que impõe à Comissão o dever de apresentar ao Parlamento Europeu e ao Conselho um relatório, nomeadamente, sobre os impactos da Diretiva aplicáveis às reservas em linha realizadas em diferentes pontos de venda.

Assim, entende-se que a Diretiva estudada, relativa às viagens organizadas e serviços de viagens conexos, proporciona a regulação de um espaço comum organizado, através de um domínio de informação e comunicação exigido uniformemente a operadores transversais visando uma integração jurídico-económica mais efetiva em rede dos Estados-Membros que compõem a União Europeia, no plano do mercado das viagens e turismo.

Por último, afirma-se que a Diretiva 2015/2302 relativa às viagens organizadas e serviços de viagens conexos, vai muito além do art. ${ }^{\circ} 195 .^{\circ}$ do Tratado de Funcionamento da União Europeia (TFUE) em matéria de turismo, que dispõe que a União completa a acção dos Estados-Membros no sector, nomeadamente, através da promoção da competitividade das empresas da União e fomento da cooperação entre os Estados-Membros, nomeadamente, através do intercâmbio de boas práticas.

Muito para além deste princípio de subsidiariedade (também enunciado no art. ${ }^{0} 6^{\circ}$ alínea d) do TFUE) em relação à acção dos Estados, a estudada Diretiva constitui um inovador marco federador e constituinte de uma nova visão estratégica de integração em rede dos Estados- Membros da União Europeia no setor do turismo e das organizações públicas e privadas de venda de serviços de viagens e turismo.

\section{CONCLUSÕES}

São conclusões da presente investigação:

A) A Diretiva UE 2015/2302, de 25 de novembro de 2015 foi aprovada como um instrumento que estabelece uma nova regulação das viagens organizadas, distinguindo este instituto da venda de outros serviços de viagem que, naturalmente, terão que ter um regime diverso e a que o legislador denominou por serviços de viagem conexos.

B) O legislador impôs um regime de harmonização máxima, não permitindo que os Estados-membros introduzam, nas legislações que transponham a diretiva, normas divergentes das previstas no diploma da União.

C) Não se encontra causalidade direta entre a máxima harmonização dos regimes relativos aos direitos dos consumidores e a proteção do mercado interno, nomeadamente no que toca à proteção dos investimentos e investidor.

D) A harmonização máxima das normas de defesa do consumidor não garante que se estabeleçam os regimes mais protetores dos direitos dos consumidores, garantindo apenas uma proteção mais uniforme, sendo que os Estados-Membros cujo 
ordenamento jurídico garante uma maior proteção dos consumidores serão obrigados a diminuir o seu standard.

E) O facto de muitas das regras consagradas na Diretiva terem uma formulação algo confusa, de difícil interpretação e pouco operativa faz com que os Estados-Membros tenham que transpor tais normas, com margem de manobra praticamente nula, o que poderá causar dificuldades interpretativas na sua aplicação.

F) Os sujeitos da relação jurídica foram, também, objeto de alterações, com a qualificação do cliente dos serviços de viagens, antes denominado consumidor e agora viajante; na oferta cria-se um conceito uniforme de operador que é dividido em dois tipos, sendo que a distinção entre estes operadores é aferida em concreto, atendendo à sua atuação e o papel desempenhado na viagem em análise (organização ou facilitação/intermediação na venda) e não de forma abstrata, tendo em conta, por exemplo, a descrição feita, por qualquer forma, da sua atividade.

G) Deixou de se prever na Diretiva o conceito de agência de viagens, instituição tradicional da distribuição e, pelo menos, na legislação portuguesa, da organização de viagens, detendo até agora, embora com exceções, a exclusividade na organização e venda de viagens organizadas e a intermediação na venda de alguns serviços turísticos.

H) A Diretiva criou um novo tipo homogéneo de ofertante na organização, venda e divulgação da viagem e serviço turistico, a que designou, como "operador" que pode atuar, seja como organizador, prestador de serviços ou distribuidor, nas faculdades e responsabilidades abertas pelo valor da informação, sua comunicação e organização na venda de serviços em turismo, quebrando-se o princípio da exclusividade às tradicionais agências de viagens da organização e venda de viagens organizadas.

I) Em relação aos tipos contratuais regulados, a viagem organizada e serviços conexos de viagem procuraram-se abranger novas possibilidades tecnológicas e processos de integração em linha na formação dos contratos, mas a distinção entre ambos foi pouco clara e operativa, não se conseguindo perceber, muitas vezes, que tipo de viagem determinado operador comercializa.

J) A Diretiva estabelece uma responsabilidade obrigatória e exclusiva do organizador da viagem, deixando aos Estados Membros a possibilidade de alargar essa proteção à agência retalhista, o que permitirá a subsistência de sistemas como o português, que introduz uma importante distorção no mercado e penaliza as agências de viagem retalhistas, não se aplicando aqui a regra da harmonização máxima da Diretiva.

K) Os problemas de responsabilidade decorrentes da contratação dos "falsos" pacotes dinâmicos, agora designados por "serviços de viagem conexos", são identificados pela Diretiva, mas a única alteração regulativa produzida para minimizar o seu impacto foi

L) a proteção em caso de insolvência que funciona, também, como marco protetor do viajante nas viagens organizadas e que obrigará a um regime de adaptação de mecanismos nacionais de garantia como o Fundo Solidário em Portugal. 
M) Os operadores de venda de viagens organizadas e serviços conexos deverão dispor de um conjunto de recursos relacionados com a criação, controlo e comunicação de informação eletrónica e informática, sendo que o valor da informação, sua angariação, produção e difusão numa rede de confiança serão vitais para a sua sobrevivência e competitividade, razão porque a Diretiva instituiu um conjunto de informações pré-contratuais e contratuais padronizadas em fichas informativas normalizadas que atuarão como um elemento integrador de economia em rede dos referidos operadores.

N) A Diretiva impulsiona também uma organização dos Estados-Membros em rede, com troca e partilha de informações, obrigatoriedade de relações frequentes, duradouras, interpessoais e interinstitucionais que favorecem a coesão e a integração social e económica nas políticas e estratégias a seguir pela União Europeia no setor das viagens e turismo e que vão muito para além do princípio da subsidiariedade em relação aos Estados que é cometido à organização no seu Tratado de Funcionamento.

\section{BIBLIOGRAFIA}

[1] ALLEE, V. "The value Evolution: Adressing Larger Implications of an Intellectual Capital and Intangible Perspective», Journal of Intellectual Capital, vol. I, $\mathrm{n}^{\mathrm{o}}$ 1, 2000.

[2] ANTUNES VARELA, João de Matos, Das Obrigações em Geral, Vol. I, Coimbra,10ª edição, 2015.

[3]APARICIO VAQUERO, J.P. y Batuecas Caletrío, A., Régimen de responsabilidad en la prestación de servicios turísticos contratados como paquetes dinámicos de turismo", en Paquetes dinámicos: problemas y soluciones jurídicas desde una perspectiva internacional (Dir. Paniza Fullana). Madrid: Ed. Dykinson, 2014.

[4]ASCENSÃO, José de Oliveira, O Direito: Introdução e Teoria Geral, Coimbra, 2004.

[5] ASSENS, C., A Gestão das redes- teçer laços sociais para o bem-estar económico,Lisboa,Piaget,2014.

[6] BAR, Von C. et all, Towards a European Civil Code, Second Revised and Expanded Edition, HARTKAMP, A et all (Eds.), Kluwers Law International, The Hague/London/ Boston, 1998.

[7] BARTOLINI, S, Metodologia de la investigación política en e. a. G.Pasquino, Ed. Manual de Ciência Política, Madrid, Alianza Universidad, 1994.

[8] BATUECAS, A e APARÍCIO J, La contratación online de servicios turísticos, Nuevas fórmulas de comercialización on line de servicios turísticos: subsunción en los tipos legales y distribución de responsabilidad, PANIZA A. (Eds.), Editorial Comares, Granada, 2013. 
[9] BUHALIS, D., LAW R., Progress in information technology and tourism management: 20 years on and 10 years after the Internet-The state of eTourism research, Tourism Management, Volume 29, issue 4, Elsevier.

[10] BULL, A., Industrial Economics and Pricing Issues Within Tourism Enterprises and Markets, Dwyer L e Forsyth P (Eds.), International Handbook of the Economics of Tourism, Northampton, Edward Elgar Publishing, 2006.

[11] Consumer Protection in the UE, Policy Overview, EPRS European Parliamentary Research Service, Jana Valant, September 2015.

[12] CAFÉ, Afonso Ribeiro, Paquetes dinámicos y la transposición de la Directiva de servicios en Portugal (desde el punto de vista de los empresarios de turismo), em Paquetes dinámicos de turismo: problemas y soluciones jurídicas desde una perspectiva internacional (Dir. Paniza Fullana), Madrid, Ed. Dykinson, 2014.

[13] CALETRIO, Alfredo B., La contratación de viajes vinculados, Revista Doctrinal Aranzadi Civil-Mercantil num.6/2016 parte Estudio, Editorial Aranzadi, SA, Cizur Menor, 2016.

[14] CASTELLS, M, The Rise of the Network Society, Cambridge, Massachusetts, Blackwell Publishers Inc., 1996.

[15] COSTA, C., Towards the improvement of the efficiency and effectiveness of tourism planning and development at the regional level: planning, organizations and networks, Guildford, Surrey University, 1996, Tese de Doutoramento.

[16] FERRIS, T., Ciência e Liberdade- Democracia, razão e leis da natureza, Lisboa, Gradiva, 2013.

[17] FULLANA, Antonia P., La protección del adquirente a distancia de servicios turísticos, en Revista de Derecho Privado, n. ${ }^{\circ} 2$ (marzo-abril 2012).

[18] FULLANA, Antonia P., Nuevas tecnologías aplicadas al turismo y sus consecuencias jurídicas: los paquetes dinâmicos, Paquetes dinámicos de turismo: problemas y soluciones jurídicas desde una perspectiva internacional, Madrid, Ed. Dykinson, 2014.

[19] GUTMAN, Kathleen, The Constitution Foundations of European Contract Law: A Comparative Analysis, Oxford University Press, 2014;

[20] JAMAL, T., Robinson M., The SAGE Handbook of Tourist Studies, SAGE Publications, London, 2009.

[21] LANA, Torres, La protección del turista en el ámbito jurídico privado, AA.VV., em La protección del turista como consumidor, Valencia, Ed. Tirant lo Blanc, 2003.

[22] MAK J., Tourism and Economy, Understanding the Economy of Tourism, University of Harvard Press, 2004.

[23] MENEZES CORDEIRO, António, Direito das Obrigações, 2. ${ }^{\circ}$ Vol., Lisboa.

[24] NYR, J., O futuro do poder (tradução de Luis Oliveira Santos (João Quina Edições) do original Future of Power), Lisboa, Circulo de Leitores,2010. 
[25] PEREIRA, A.M., Introdução ao Direito e às Obrigações, $4^{\mathrm{a}}$ edição, Coimbra, Almedina, 2015.

[26] PIRES, F.L. Introdução à Ciência Política, Porto, Universidade Católica Portuguesa,1998.

[27] Relatório referente ao Livro Verde sobre a revisão do acervo relativo à defesa do consumidor (2007/2010 (INI)) Comissão do Mercado Interno e da Proteção dos Consumidores, relatora Béatrice Patrie,16.07.2007.

[28] SANTOS, José Augusto Cerqueira, A Harmonização do Direito do Consumo - Recentes desenvolvimentos ao nível europeu e nacional, Porto, Faculdade de Direito, 2015, Tese de Mestrado.

[29] SMITS, Jan, Full Harmonization of Consumer Laws? A Critique of the Draft of the Directive on Consumer Rights, European Revue of Private Law, 1-2010, Kluver Law International BV, Great Britain.

[30] TORRES, Carlos, Modificações no Fundo de Garantia Decorrentes da Nova Diretiva das Viagens Organizadas, in Publituris, 18 de Fevereiro de 2016.

[31] TORRES LANA, J, Derechos y Garantias del Contratante y del Usuário de Serviços Turisticos Adquiridos Online, Nuevas fórmulas de comercialização on line de servicios turísticos: subsunción en los tipos legales y distribución de responsabilidad, PANIZA A. (Eds.), Editorial Comares, Granada, 2013,

[32] TWIGG-FLESNER, C., Good-Bye Harmonisation by Directives, Hello Cross-Border only Regulation? - A way forward for EU Consumer Contract Law”, http://ec.europa.eu/justice/news/consulting_public/0052/contributions/309_en.pdf.

[33] VIDAL, João A., La responsabilidad de las empresas turísticas frente a la problemática de los paquetes dinámicos: el caso de Portugal, Paquetes dinámicos de turismo: problemas y soluciones jurídicas desde una perspectiva internacional, Madrid: Ed. Dykinson, 2014.

[34] Working Document on the Council Directive 90/314/EEC of 13 June 1990 on package travel, package holidays and package tours, 26.07.2007, Brussels. 